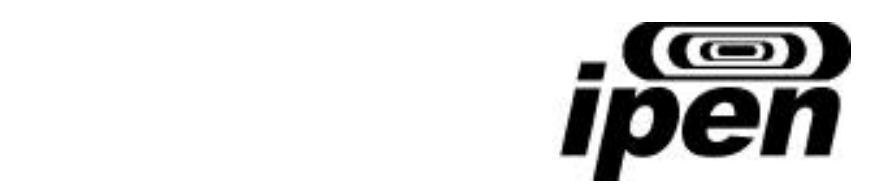

INSTITUTO DE PESQUISAS ENERGÉTICAS E NUCLEARES Autarquia Associada à Universidade de São Paulo

\title{
DESCONTAMINAÇÃO DE EMBALAGENS DE CLORPIRIFÓS UTILIZANDO O PROCESSO DE OXIDAÇÃO AVANÇADA POR RADIAÇÃO IONIZANTE
}

Manoel Nunes Mori

Tese apresentada como parte dos requisitos para obtenção do Grau de Mestre em Ciência na Área de Tecnologia Nuclear - Aplicações.

Orientadora:

Dra. Celina Lopes Duarte

SÃO PAULO 


\section{AGRADECIMENTOS}

Esta tese pôde tornar-se realidade graças ao apoio de várias instituições e pessoas. Desejo agradecer:

- Ao inpEV, na pessoa do Sr. Rogério Fernandes de Souza, que nos forneceu as embalagens contaminadas;

- À Graham Packaging do Brasil que nos forneceu as embalagens não contaminadas;

- À Fapesp pelo apoio financeiro;

- Ao Ipen, na pessoa do Sr. Superintendente Dr. Cláudio Rodrigues pela possibilidade oferecida de realização deste trabalho;

- À Dra. Celina Lopes Duarte, pela orientação;

- À Dra. Maria Helena de Oliveira Sampa pelo apoio e correções sugeridas;

- A todos os colegas do Centro de Tecnologia das Radiações, CTR, do Ipen que direta e indiretamente colaboraram na realização deste trabalho.

Sou extremamente grato a todos. 


\section{DESCONTAMINAÇÃO DE EMBALAGENS DESCARTADAS DE CLORPIRIFÓS UTILIZANDO O PROCESSO DE OXIDAÇÃO AVANÇADA POR RADIAÇÃO IONIZANTE}

\section{Manoel Nunes Mori}

\section{RESUMO}

O descarte de embalagens vazias dos agrotóxicos sem fiscalização e controle pode gerar problemas ambientais, afetando a saúde do homem, dos animais e da vida silvestre. Entre os inseticidas comerciais, o clorpirifós tem uma importância significativa por ser amplamente utilizado e persistente no ambiente. $\mathrm{O}$ ataque do radical hidroxila, ${ }^{\circ} \mathrm{OH}$ é o processo mais eficiente de oxidação química de compostos orgânicos. A degradação de clorpirifós induzida por radiação gama foi estudada em amostras de água e em embalagens de polietileno. Embalagens de polietileno de alta densidade coextrudada em camadas sobrepostas, COEX, contaminadas com clorpirifós foram irradiadas com radiação gama em fonte de Co-60 do tipo "Gammacell" e do tipo "irradiador de grande porte". As análises de clorpirifós e solventes, assim como dos subprodutos formados foram realizadas por cromatografia a gás associada à espectrometria de massa. A radiação ionizante se mostrou uma técnica eficiente na degradação do inseticida clorpirifós nestas embalagens. 


\title{
DECONTAMINATION OF USED PESTICIDE PACKAGING USING ADVANCED OXIDATION PROCESS BY IONIZING RADIATION
}

\section{Manoel Nunes Mori}

\begin{abstract}
The discharge of empty plastic packaging of pesticides can be an environmental concern causing problems to human health, animals and plants if done without inspection and monitoring. Among the commercial pesticides, chlorpyrifos has significant importance because of its wide distribution and extensive use and persistence. The hydroxil $\mathrm{OH}$ atack is the most efficient process of chemical oxidation. The radiation-induced degradation of chlorpyfifos in liquid samples and in polyethylene pack was studied by gamma-radiolysis. Packaging of high density polyethylene tree layer coextruded, named COEX, and water samples contaminated with chlorpyrifos, were irradiated using both, a multipurpose Co-60 gamma irradiator and a gamma source with 5,000 Ci total activity, Gammacell type. The chemical analysis of the chlorpirifos and by-products were made using a gas chromatography associated to the mass spectrometry. Gamma radiation was efficient for removing chlorpyrifós from the plastic packaging in all studied cases.
\end{abstract}




\section{SUMÁRIO}

Página

1.0 INTRODUÇÃO....................................................................

1.1 Contaminação ambiental por agrotóxicos .................................

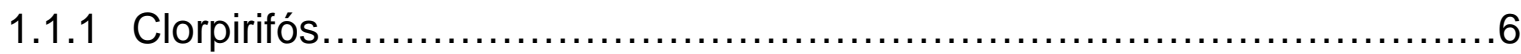

1.1.2 Comportamento do clorpirifós no ambiente ...............................

1.2 O Problema das embalagens de agrotóxicos..............................13

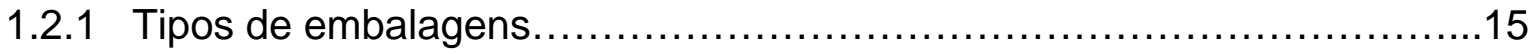

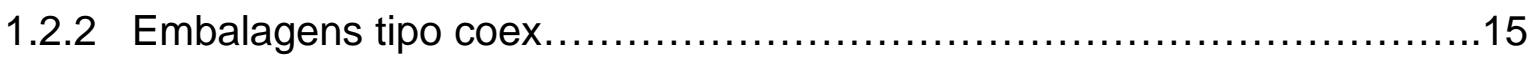

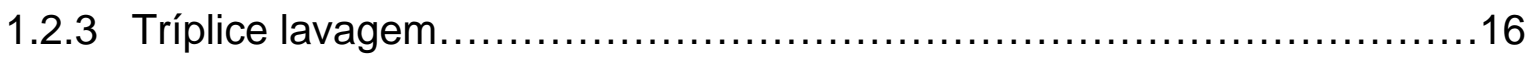

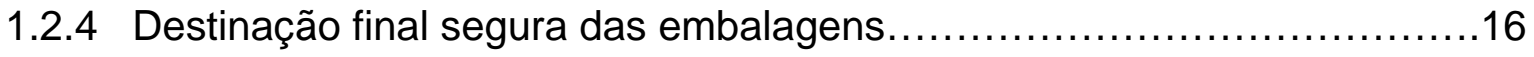

1.3 Processos de oxidação avançada e suas aplicações ambientais............18

1.3.1 Uso da tecnologia nuclear na recuperação ambiental.......................18

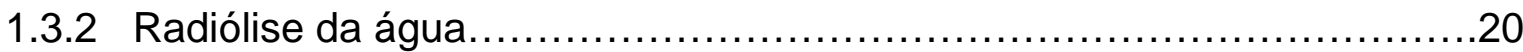

1.3.3 Aplicação da radiação ionizante na degradação de agrotóxicos.............24

1.4 Métodos de detecção de agrotóxicos....................................27

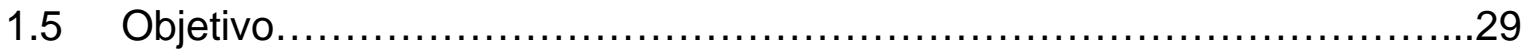

2.0 MATERIAIS E MÉTODOS...................................................

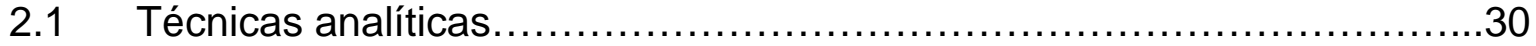

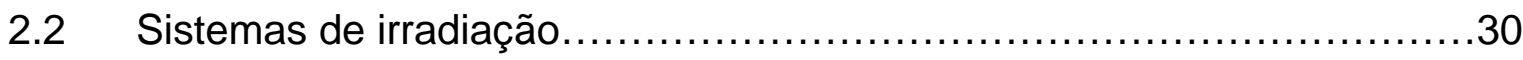

2.3 Ensaio com o clorpirifós em solução..........................................31

2.3.1 Preparação das amostras de clorpirifós por diluição em acetonitrila........32

2.3.2 Preparação das amostras de clorpirifós por diluição em acetonitrila

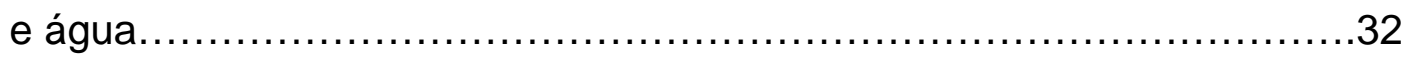

2.4 Ensaios com as embalagens contaminadas com clorpirifós..................33

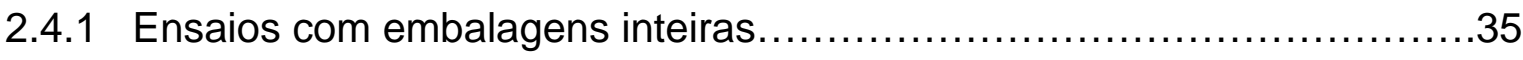

2.4.2 Ensaios com embalagens picadas........................................... 35

Ensaios com embalagens picadas em frascos de vidro.....................35

Ensaios com embalagens picadas em sacos de polietileno..................36

3.0 RESULTADOS E DISCUSSÃO................................................ 
3.1 Ensaios com o clorpirifós em solução …............................... 37

3.1.1 Análise dos subprodutos formados... ................................. 40

3.1.2 Efeito da adição de água na degradação do clorpirifós................... 43

3.2 Degradação do clorpirifós presente nas embalagens......................47

3.2.1 Embalagens irradiadas inteiras............................................47

3.2.2 Embalagens irradiadas picadas ....................................... 49

Ensaios com embalagens picadas em frascos de vidro......................49

Ensaios com embalagens picadas em sacos de polietileno................50

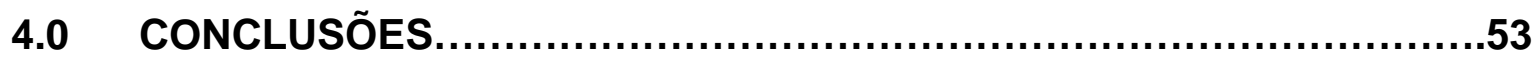

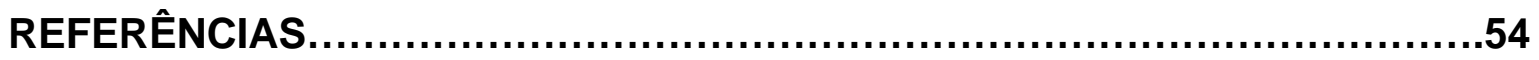




\subsection{INTRODUÇÃO}

Com um crescimento anual de 85 milhões de habitantes a população mundial deverá ultrapassar os 8 bilhões de habitantes em 2020. O fornecimento de alimentos: leite, carne, cereais, frutas e verduras de alta qualidade é um desafio para o setor agrícola. A área reservada para agricultura não pode ter prioridade aos demais espaços que também devem ser reservados para a construção de estradas, edificação de cidades com ruas, residências, fábricas e hospitais para o bem estar da população e florestas para manutenção da vida selvagem e ambiente.

Usando tecnologias avançadas, sementes melhoradas geneticamente, fertilizantes, irrigação e mecanização é possível duplicar a produção de alimentos sem alterar a área cultivada. O uso de agrotóxicos é um dos principais fatores que garante estes altos rendimentos na lavoura. Apesar do efeito nocivo à saúde das pessoas e dos animais e ao ambiente, deve ser considerado um veneno útil e seu emprego deve ser controlado para evitar aplicações desnecessárias e conscientização do potencial poluidor para rios, lagos e águas subterrâneas.

O acúmulo de resíduos sólidos no ambiente de áreas rurais com o descarte de embalagens de agrotóxicos contaminadas causa poluição e contaminação em rios, águas subterrâneas e no solo. Se corretamente lavadas, 95\% das embalagens de agrotóxicos podem ser recicladas como matéria-prima para a fabricação de novos produtos contribuindo para reduzir os danos ambientais. Com o objetivo de recolhimento e processamento das embalagens vazias de produtos fitossanitários e domissanitários foi criado em 2001 o inpEV que juntamente com uma rede de recicladoras, processa cerca de $90 \%$ das embalagens devolvidas, o restante, como não podem ser recicladas por estarem contaminadas, são incineradas.

A aplicação das radiações ionizantes na decomposição de compostos orgânicos tóxicos é uma alternativa inovadora e que tem se tornado de grande relevância na solução de problemas de poluição ambiental, cuja solução não é alcançada por tecnologias convencionais. 


\subsection{Contaminação Ambiental por Agrotóxicos}

A água ocupa no planeta a proporção de $2 / 3$ de sua superfície formando os oceanos, rios, mares lagos e geleiras. Derísio ${ }^{(1)}$ considera que uma água está descaracterizada de suas propriedades essenciais para abastecimento público, industrial, irrigação e suporte para a vida aquática por diferentes tipos de fontes poluidoras, que podem ser divididas em:

- Poluição natural por decomposição de vegetais e animais mortos, salinização;

- Poluição industrial causada por derramamento acidental ou rotineiro por indústrias, fábricas e frigoríficos;

- Poluição urbana gerada por esgotos domésticos lançados nos corpos de água sem tratamento;

- Poluição agropastoril relacionada com o uso de agrotóxicos e fertilizantes.

Quanto ao risco ambiental os resíduos sólidos são classificados $\mathrm{em}^{(2)}$ :

- Classe I - Resíduos perigosos. Podem apresentar riscos à saúde pública e ao ambiente por

- causa de suas características de inflamabilidade, corrosividade, reatividade, toxicidade e patogenicidade.

- Classe Ila - Não-inertes. Incluem nesta classe os resíduos potencialmente biodegradáveis ou combustíveis.

- Classe Illb - Resíduos inertes. São os resíduos considerados inertes e não combustíveis.

"Agrotóxicos e afins são produtos e agentes de processos físicos,

químicos ou biológicos, destinados ao uso nos setores de produção, no armazenamento e beneficiamento de produtos agrícolas, nas pastagens, na proteção de florestas, nativas ou plantadas e de ambientes urbanos, hídricos e industriais, cuja finalidade seja alterar a composição da flora ou da fauna, a fim de preservá-las da ação danosa de seres vivos considerados nocivos; bem como as substâncias e produtos empregados como 
desfolhantes, dessecantes, estimuladores e inibidores de crescimento, ${ }^{\text {,(3) }}$. Esta definição engloba todos os produtos de uso agrícola pertencentes a diferentes classes químicas e finalidades, como os inseticidas, os acaricidas, os formicidas, os larvicidas, os bernicidas, os carrapaticidas, os moluscidas, os nematicidas, os rodenticidas, os raticidas, os bactericidas, os fungicidas, os herbicidas e os arbusticidas.

De acordo com Mídio e da Silva(4) inseticida tem a seguinte definição:

"é toda substância ou mistura de substâncias utilizadas com a finalidade de prevenir ou minimizar o aparecimento, destruir e repelir insetos e ácaros, bem como larvas e outras formas de seu desenvolvimento".

A categoria de agrotóxico mais utilizada no Brasil são os herbicidas seguidos pelos inseticidas e fungicidas. Os inseticidas acaricidas, conforme suas características químicas, são classificados em inseticida organofosforado, inseticida derivado do ácido carbâmico, inseticida organoclorado, piretróides, formamidinas, dinitrofenóis, organitinas e inorgânicos.

A utilização de agrotóxicos vem crescendo ano após ano. A demanda das principais culturas chegou a 160,1 mil toneladas de defensivos em 2003, o que coloca o Brasil em oitavo lugar no mundo, com um crescimento médio de $11,4 \%$ ao ano, em comparação com um aumento de 1\% a 2\% ao ano nos países desenvolvidos. As culturas que mais consomem agrotóxicos, pela ordem, são soja $(38,06 \%)$, cana-de-açúcar $(11,51 \%)$, algodão $(9,09 \%)$, milho $(7,82 \%)$, citros $(5,94 \%)$, trigo $(3,48 \%)$, feijão $(3,47 \%)$, batata $(2,49 \%)$, arroz $(2,45 \%)$ e café $(2,42 \%)$. As demais culturas representam $13,27 \%$ do consumo nacional. Esses dados referem-se ao ano de 2002. O volume de ingredientes ativos consumidos no Brasil, de 3,2 quilos por hectare no ano de 2000, é semelhante ao dos Estados Unidos em 1994/95, que era de 3,4 quilos por hectare ${ }^{(5,6)}$. Na Figura 1 é mostrado a evolução das vendas de agrotóxicos por ingrediente ativo no período de 1992 a 2002. 


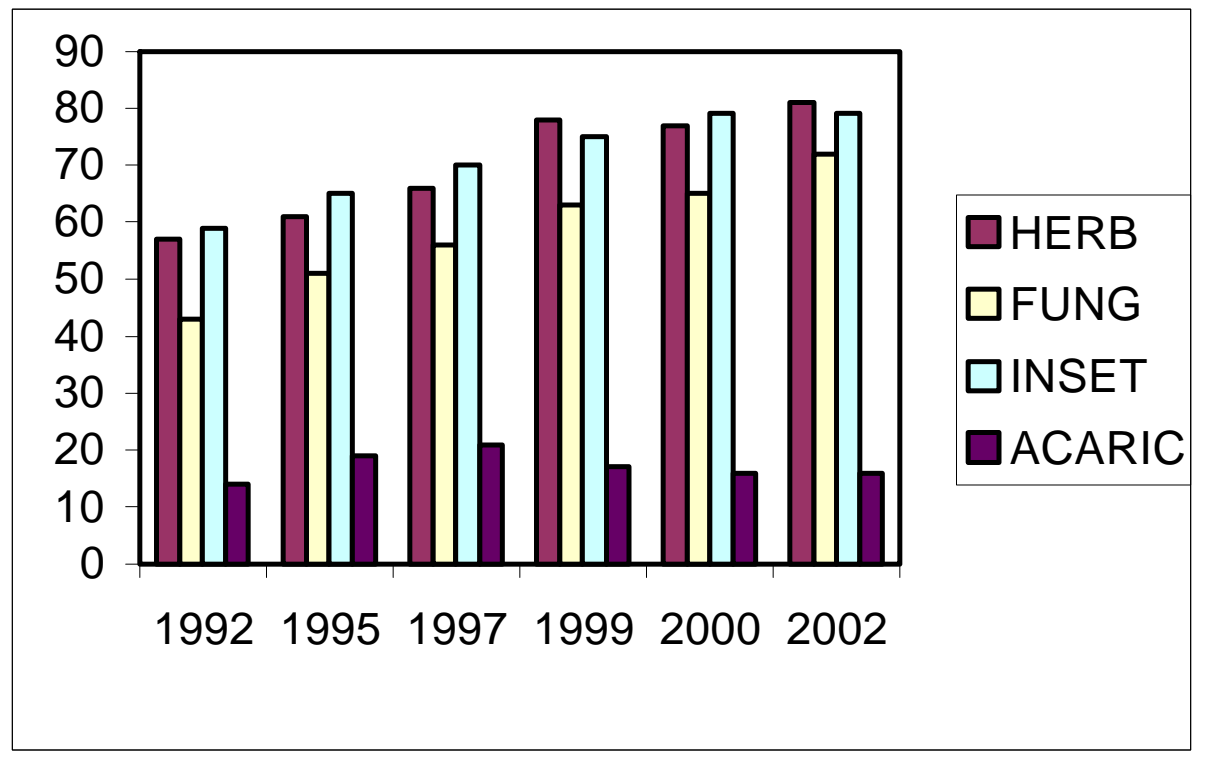

FIGURA 1. Evolução das vendas de agrotóxicos por ingrediente ativo no período de 1992 a $2002^{(7)}$.

A utilização destes agrotóxicos na agricultura tem um impacto positivo e frequentemente dramático na produção agrícola, pois podem deixar resíduos tanto nos alimentos como no meio ambiente e por isso todo esforço precisa ser feito para assegurar que sua aplicação seja segura e para prevenir efeitos danosos ao meio ambiente e à saúde humana.

Os inseticidas agem no organismo dos insetos por contato, ingestão, fumigação e de modo sistêmico quando incorporado ao sistema lenhoso aniquilam os insetos que alimentam da seiva das plantas. Conforme o tipo de formulação podem ser: pós, grânulos, pós molháveis, soluções aquosas ou em solventes orgânicos ${ }^{(4)}$.

Os inseticidas acaricidas fabricados no Brasil são classificados conforme suas características químicas em ${ }^{(8)}$ :

- Inseticidas orgnofosforados;

1. Derivados do ácido fosfórico - monocrotophos;

2. Derivados do ácido tiofosfórico com os isômeros tiono e tiol - clorpirifós, fenitrothion, fenthion, parathion metilico, pirimiphos methyl, profenofos, triazophos; 
3. Derivados do ácido ditiofosfórico - dimetoato, ethion, fentoato, malathion, methidathion;

4. Derivados do ácido fosfônico - triclorfon;

5. Outros - acefato e metamidofos.

- Inseticida derivado do ácido carbâmico - aldicarb, carbaryl, carbofuran, methomyl, thiodicarb, benfuracarb, carbosulfan;

- Piretroides - bifenthrin, betacyflutrin, gama cialotrina, lambdacyhalohtrin, cypermethrin, alfacypermetrina, betacipermetrina, zetacipermetrina, deltametrina, fenpropathrin, esfenvalerate, permetrin;

- $\quad$ Formamidinas - formetanato;

- Inorgânicos - terra diatomacea, remove a cera da epicuticula de modo que os insetos morrem por dessecação.

As formulações de inseticidas são classificadas, de acordo com a Associação Brasileira de Normas Técnicas ${ }^{(9)}$, conforme a sua solubilidade em água ou solventes orgânicos, para aplicação direta, para tratamento de sementes e para formulações especiais.

$\mathrm{Na}$ Tabela 1 é apresentado os tipos de formulações e as respectivas siglas de inseticidas para serem diluídos em água, elaboradas pelo "Global Crop Protection Federation", GCPF, adotadas pela "Food Agricultural Organization", $\mathrm{FAO}$, e aceitas internacionalmente.

A principal característica utilizada como referência para antever o comportamento ambiental dos inseticidas são as propriedades físico-químicas. Segundo Prata ${ }^{(10)}$, a pressão de vapor de um inseticida indica o comportamento que este composto tem em volatilizar. São classificados em muito voláteis, $P \geq 10^{-2}$ mmHg, medianamente voláteis, $10^{-4} \leq \mathrm{P} \geq 10^{-3} \mathrm{mmHg}$, pouco volteis, $10^{-7} \leq \mathrm{P}$ $\geq 10^{-5} \mathrm{mmHg}$ e não voláteis, $\mathrm{P} \geq 10^{-8} \mathrm{mmHg}$. Esses valores são em função da temperatura. 
TABELA 1. Tipos de formulação de inseticidas

\begin{tabular}{l|l}
\multicolumn{2}{c}{ para diluição em água ${ }^{(9)}$} \\
\hline FORMULAÇÃO & SIGLAS \\
\hline Suspensão de encapsulado & CS \\
Concentrado dispersível & DC \\
Concentrado emulsionável & EC \\
Emulsão de água em óleo & EO \\
Emulsão de óleo em água & EW \\
Microemulsão & ME \\
Suspensão concentrada & SC \\
Suspo-emulsão & SE \\
Granulado solúvel & SG \\
Concentrado solúvel & SL \\
Pó solúvel & SP \\
Tablete & TB \\
\hline
\end{tabular}

Cabe ao Ministério da Saúde ${ }^{(11)}$ avaliar e classificar toxicologicamente os inseticidas quanto aos produtos técnicos, ingredientes ativos e produtos formulados. Na Tabela 2 são apresentados os graus de toxicidade, a classe toxicologica para as formulações líquidas e sólidas, o limite inferior e superior da dose letal oral e dérmica para ratos e a cor da faixa no rótulo dos inseticidas.

TABELA 2. Classificação toxicologica dos inseticidas pelo Ministério da Saúde ${ }^{(11)}$

\begin{tabular}{|c|c|c|c|c|c|}
\hline TOXICIDADE & CLASSE & FORMULAÇÃO & $\begin{array}{c}\text { DL } 50 \\
\text { ORAL } \\
\text { (mg/kg) }\end{array}$ & $\begin{array}{c}\text { DL } 50 \\
\text { DÉRMICA } \\
\text { (mg/kg) }\end{array}$ & $\begin{array}{c}\text { COR DA } \\
\text { FAIXA } \\
\text { NO } \\
\text { RÓTULO }\end{array}$ \\
\hline $\begin{array}{l}\text { Extremamente } \\
\text { Tóxico }\end{array}$ & $\mathrm{I}$ & $\begin{array}{l}\text { Líquida } \\
\text { Sólida }\end{array}$ & $\begin{array}{l}<20 \\
<5\end{array}$ & $\begin{array}{l}<40 \\
<10\end{array}$ & Vermelha \\
\hline Altamente tóxico & II & $\begin{array}{l}\text { Líquida } \\
\text { Sólida }\end{array}$ & $\begin{array}{c}>20 \text { e }<200 \\
>5 \text { e }<50\end{array}$ & $\begin{array}{l}>40 \text { e }<400 \\
>10 \text { e }<100\end{array}$ & Amarela \\
\hline $\begin{array}{l}\text { Medianamente } \\
\text { Tóxico }\end{array}$ & III & $\begin{array}{l}\text { Líquida } \\
\text { Sólido }\end{array}$ & $\begin{array}{c}>200 \text { e }<2000 \\
>50 \text { e }<500\end{array}$ & $\begin{array}{l}>400 \text { e }<4000 \\
>100 \text { e }<1000\end{array}$ & Azul \\
\hline Pouco tóxico & IV & $\begin{array}{l}\text { Líquida } \\
\text { Sólida }\end{array}$ & $\begin{array}{l}>2000 \\
>500\end{array}$ & $\begin{array}{l}>4000 \\
>1000\end{array}$ & Verde \\
\hline
\end{tabular}

\subsubsection{Clorpirifós}

O clorpirifós, O,O-dietil O-(3,5,6-tricloro-2-piridila) fosforotioato, é um inseticida organofosforado que foi inicialmente fabricado e comercializado em 
1965 pela Dow Chemical Company nos Estados Unidos e atualmente é um dos cinco inseticidas mais comercializados com mais de 900 formulações diferentes ${ }^{(12)}$.

O mecanismo de ação toxicológica do clorpirifós é a inibição da enzima acetilcolinesterase que resulta no acúmulo da acetilcolina, um neuro transmissor extremamente tóxico presente em insetos e animais, causando a interrupção dos impulsos nervosos. Alguns sintomas de intoxicação por clorpirifós são dor de cabeça, vertigem, transpiração excessiva, perda de coordenação, espasmos, tremores, náusea, diarréia e salivação ${ }^{(12)}$.

$\mathrm{Na}$ Tabela 3 são apresentadas as principais propriedades físicoquímicas do clorpirifós. Na Tabela 4 têm-se uma lista das pragas controladas pelo clorpirifós em diferentes tipos de cultura e na Tabela 5 uma relação das empresas nacionais que comercializam o clorpirifós com suas respectivas marcas comerciais, classe toxicologica, concentração e formulação.

\section{Comportamento do Clorpirifós no Ambiente}

A principal fonte de contaminação ambiental com inseticidas é o uso agrícola para controlar pragas. Anualmente toneladas são utilizadas para esse fim atingindo alvos secundários. Outras fontes de contaminação são o uso em áreas residenciais, para combater insetos como as baratas e formigas, e urbanas em campanhas de saúde para controle de vetores que transmitem a dengue, malária, febre amarela e doença de chagas.

A contaminação também pode ocorrer durante 0 transporte, distribuição e armazenamento. No ambiente vários sistemas biológicos são afetados. No solo e na água são quimicamente e biologicamente transformados em outros produtos. 
TABELA 3. Propriedades físico-químicas do Clorpirifós $^{(13)}$

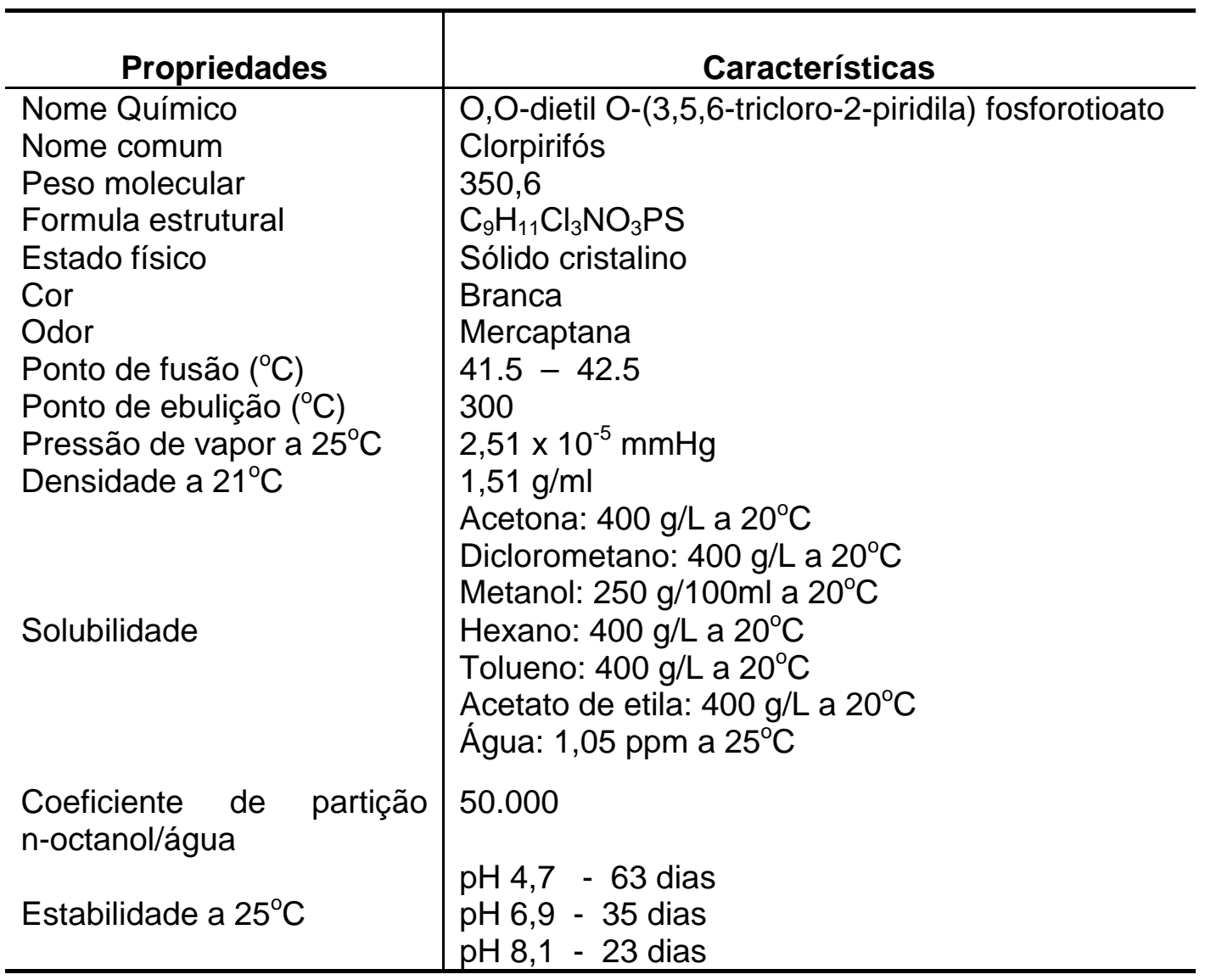

TABELA 4. Usos do Clorpirifós na Agricultura(14)

\begin{tabular}{l|l}
\hline Tipo de Cultura & Pragas Controladas \\
\hline Algodão & $\begin{array}{l}\text { Curuquere } \\
\text { Ácaro Branco } \\
\text { Broca } \\
\text { Bicho mineiro } \\
\text { Pulgão amarelo das folhas } \\
\text { Pulgão das espigas } \\
\text { Mosca das frutas } \\
\text { Cochinilha parlatoria } \\
\text { Pulgão } \\
\text { Curuquere } \\
\text { Cevada }\end{array}$ \\
Citrus & $\begin{array}{l}\text { Lagarta da vagem } \\
\text { Lagarta do cartucho } \\
\text { Lagarta rosca }\end{array}$ \\
\hline Feijão &
\end{tabular}


TABELA 5. Empresas que comercializam o clorpirifós para diluição em água ${ }^{(15)}$

\begin{tabular}{|c|c|c|c|}
\hline EMPRESA & $\begin{array}{c}\text { MARCA } \\
\text { COMERCIA } \\
\text { L }\end{array}$ & CLASSE & $\begin{array}{c}\text { CONCENTRAÇAO } \\
(\mathrm{g} / \mathrm{l})\end{array}$ \\
\hline $\begin{array}{c}\text { Bayer } \\
\text { CropScience }\end{array}$ & Astro & III & 450 \\
\hline Fersol & $\begin{array}{l}\text { Clorpirifós } \\
480 \mathrm{CE}\end{array}$ & II & 480 \\
\hline $\begin{array}{c}\text { Dow } \\
\text { AgroScience }\end{array}$ & $\begin{array}{l}\text { Clorpirifós } \\
\text { Fersol } \\
480 \mathrm{CE}\end{array}$ & II & 480 \\
\hline Crompton & $\begin{array}{l}\text { Klorpan } \\
480 \mathrm{CE}\end{array}$ & II & 480 \\
\hline Agripec & $\begin{array}{l}\text { Klorpan } \\
480 \mathrm{CE}\end{array}$ & ॥ & 480 \\
\hline $\begin{array}{c}\text { Dow } \\
\text { AgroScience }\end{array}$ & $\begin{array}{l}\text { Lorsban } \\
480 \mathrm{BR}\end{array}$ & II & 480 \\
\hline Cheminova & $\begin{array}{l}\text { Nufos } \\
480 \mathrm{CE}\end{array}$ & III & 480 \\
\hline Monsanto & $\begin{array}{l}\text { Nufos } \\
480 \mathrm{CE}\end{array}$ & III & 480 \\
\hline Milenia & Pyrinex & ॥ & 480 \\
\hline Basf & Verter & ॥ & 480 \\
\hline $\begin{array}{c}\text { Dow } \\
\text { AgroScience }\end{array}$ & Sabre & III & 450 \\
\hline
\end{tabular}

Após aplicação do inseticida uma parte fica retido nas folhagens e a porção maior do que foi aplicado atingirá o solo por gotejamento ou pela ação da água da chuva ou de irrigação. No solo haverá uma interação solo/inseticida e o resultado dessa interação poderá ser a volatilização, retenção ou percolação dependendo das propriedades físico-químicas do inseticida e das características do solo, ou sofrerão um deslocamento superficial pela ação de chuvas torrenciais atingindo rios e lagos.

Padovani e Capri ${ }^{(16)}$ registraram a taxa de dissipação do clorpirifós pulverizado em uma plantação de citrus na Província de Catania região da Sicília. As amostras foram recolhidas nas posições laterais aéreas do pomar em pedaços de papel de $5 \mathrm{~cm}^{2}$ colocados horizontalmente em relação ao solo em estacas de 
madeira, em um canal de irrigação que cruza o pomar e no solo. Os valores medidos após aplicação ficaram entre $0,04 \%$ e 0,19\%, no solo e na água, da dose aplicada que é um valor muito baixo comparado com outros artigos para condição semelhante. Os autores concluíram que esta variação ocorreu pela flutuação da velocidade e direção do vento.

Laabs e colaboradores ${ }^{(17)}$ estudaram o potencial de contaminação de oito inseticidas, 4 polares e 4 apolares incluindo o clorpirifós, no cerrado brasileiro em um campo experimental perto de Cuiabá no Mato Grosso. O comportamento ambiental dos inseticidas em clima temperado é conhecido, porém, em solos de clima tropical é pouco conhecido. As análises demonstraram que o clorpirifós é altamente dissipado por volatilização favorecida pelas condições climáticas com temperatura diária máxima variando de $35^{\circ} \mathrm{C}$ a $45^{\circ} \mathrm{C}$.

Na Figura 2 é mostrada a curva da perda do clorpirifós para o ambiente na volatilização, lixiviação e degradação pelo tempo em dias, no cerrado brasileiro em um campo experimental próximo a Cuiabá no Mato Grosso. Como pode ser observado a taxa de decaimento é de $50 \%$ no primeiro dia após aplicação e cai lentamente após esse período. Na primeira etapa ocorre a dissipação e depois a persistência conforme proposto por Matsumura ${ }^{(18)}$.

Cinco tipos de solos com diferentes conteúdos de matéria orgânica foram usados para estudar o fenômeno de sorção (absorção e desorção) do clorpirifós por Felsot e Dahm ${ }^{(19)}$. A absorção nos diferentes tipos de solo foi nesta ordem: turfa $>$ harps $>$ clarion $>$ thurman $>$ sarpy, cujas porcentagens de matéria orgânica são respectivamente: $31,65 \%-6,55 \%-4,56 \%-1,84 \%$ e $0,88 \%$. Logo depois todos os solos foram oxidados com água oxigenada para a destruição da matéria orgânica e verificou-se uma redução na absorção e aumento da desorção do inseticida. A sorção está relacionada com o teor de matéria orgânica do solo, e este fenômeno pode influenciar a translocação, volatilização e persistência do inseticida. 


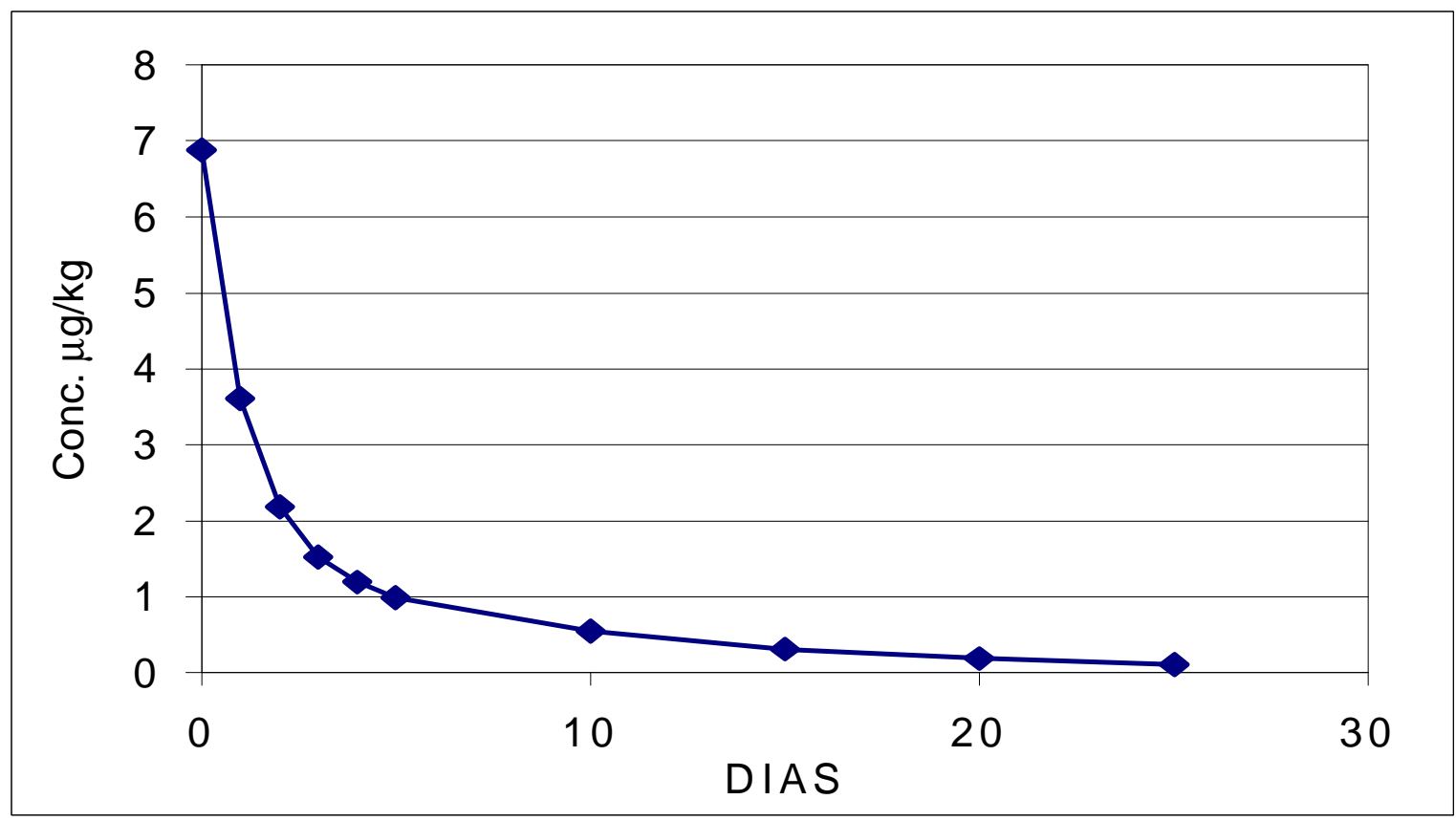

FIGURA 2. Perdas do clorpirifós no cerrado brasileiro ${ }^{(17)}$

Trinta e sete tipos de solos diferentes provenientes de diferentes países: Estados Unidos, Canadá e Brasil com acidez e alcalinidade entre 3,8 a 8,5 foram submetidos a testes em laboratório por Racke e colaboradores ${ }^{(20)}$ para verificar qual faixa de $\mathrm{pH}$ afeta a taxa de hidrólise do clorpirifós. Todos os solos foram irradiados com raios gama de uma fonte de Co-60 para eliminar interferência de degradação biológica. As amostras do solo após serem esterilizadas foram contaminadas com clorpirifós e adicionado uma alíquota de água e armazenadas em local escuro. O principal fator que afeta a hidrólise do clorpirifós no solo é o $\mathrm{pH}$. Em solos cujo $\mathrm{pH}$ varia de ácido a neutro, $\mathrm{pH} \leq 7$, a hidrólise é lenta, em solos alcalinos, $\mathrm{pH}>7$, a hidrólise é rápida, contribuindo para a principal forma de degradação do inseticida.

Noblet e colaboradores ${ }^{(21)}$ propuseram uma investigação sobre a hidrólise do clorpirifós em condições reais de campo onde os parâmetros temperatura, $\mathrm{pH}$ e matéria orgânica são constantes. Água de três locais diferentes da bacia do Rio São Joaquim na Califórnia foram coletados e o conteúdo de matéria orgânica era de $3,7 \mathrm{mg} / \mathrm{l} ; 6,5 \mathrm{mg} / \mathrm{l}$ e $34,5 \mathrm{mg} / \mathrm{l} \mathrm{e} \circ \mathrm{pH} 8$. Mantendo as características da água do rio e variando a temperatura até $40^{\circ} \mathrm{C}$ a taxa de hidrólise foi maior na água Milli-Q comparada com as amostras do rio. Esse resultado está de acordo com outros autores que encontraram uma taxa de redução de 7 a 11 vezes em meio alcalino para o clorpirifós que foi absorvido pela matéria orgânica. 
A umidade relativa do ar e a temperatura são dois fatores que têm influência na perda do clorpirifós por volatilização. Amostras de solo seco (Sultan silt) foram contaminadas com clorpirifós e mantidas em ambiente sem luz nas temperaturas de $5^{\circ} \mathrm{C}, 15^{\circ} \mathrm{C}, 25^{\circ} \mathrm{C}, 35^{\circ} \mathrm{C}$ e $45^{\circ} \mathrm{C}$. Metade da concentração inicial foi perdida em 20 dias, 8 dias e 3 dias nas temperaturas de $5^{\circ} \mathrm{C}, 25^{\circ} \mathrm{C}$ e $35^{\circ} \mathrm{C}$, respectivamente e em 18 horas a $45^{\circ} \mathrm{C}$.

Outro experimento foi realizado com o mesmo tipo de solo e a mesma concentração de clorpirifós com a temperatura fixa de $35^{\circ} \mathrm{C}$ e as umidades relativas de $30 \%$ e $91 \%$. A concentração do composto resultante da hidrólise do clorpirifós, 3,5,6-tricloro-2-piridinol (3,5,6 TCP), no solo com 30\% de umidade foi de $75 \%$ e perdas por volatilização de $20 \%$. No solo com umidade de $91 \%$ foi observado um comportamento inverso com formação de $25 \%$ de TCP e $70 \%$ de perdas por volatilização. Getzin ${ }^{(22)}$ concluiu que a umidade relativa do ar é o principal fator que perturba a perda do clorpirifós por volatilização.

Marino e Ronco ${ }^{(23)}$ taxaram a concentração de clorpirifós aplicado nas plantações de soja no Pampa argentino nas águas superficiais e em sedimentos transportados pela ação de chuvas em uma área banhada por cinco afluentes do Rio Paraná. As amostras foram recolhidas em um período de 2 anos, de outubro de 2002 a março de 2004. A ocorrência de clorpirifós está relacionada com a ocasião de chuvas após pulverização, $42 \%$ das amostras de água e todas as amostras de sedimento apresentaram níveis detectáveis de clorpirifós. O crescente uso de inseticidas na região é a principal fonte de contaminação para cursos de água como o Rio Paraná.

Jergentz e colaboradores ${ }^{(24)}$ determinaram a concentração do clorpirifós em sedimentos, partículas em suspensão e água dos Rios Brown e Horqueta em uma área de cultivo de soja no pampa argentino. A região escolhida é caracterizada por grandes perdas de solo causada por erosão no período das chuvas, de novembro a março, que coincide com a época de plantio e uso de inseticidas. No Rio Brown as concentrações foram de $226 \mu \mathrm{g} / \mathrm{kg}$ e 0,45 $\mu \mathrm{g} / \mathrm{l}$ nas partículas em suspensão e na água. No Rio Horqueta as concentrações foram de $53 \mu \mathrm{g} / \mathrm{kg}$ e 0,3 $\mu \mathrm{g} / \mathrm{l}$ nos sedimentos e na água. A vazão do Rio Horqueta é maior do que o Rio Brown e este fator contribuiu para a dissipação do inseticida. 


\subsection{O Problema das Embalagens de Agrotóxicos}

Outro problema relacionado à utilização de agrotóxicos é a descontaminação e o destino final dado às suas embalagens ${ }^{(25)}$. Durante vários anos, a iniciativa privada e órgãos do governo vêm trabalhando em conjunto num programa nacional para o destino final das embalagens e os principais ensinamentos sobre o tema abordado têm surgido por iniciativas da indústria e da participação voluntária de diversos segmentos da sociedade. As parcerias estabelecidas e os convênios firmados com empresas, entidades, revendedores e cooperativas permitiram a implantação de uma rede de Unidades Centrais de Recebimento de Embalagens no Brasil, que hoje ajuda a reduzir o número de embalagens abandonadas na lavoura, estradas e às margens de mananciais de água.

O Instituto Nacional de Processamento de Embalagens Vazias, inpEV, foi criado em 2001 e entrou em operação em Janeiro de 2002 com o objetivo de implantar um sistema ágil e eficiente de processamento de embalagens vazias de defensivos agrícolas. A meta do inpEV e de seus parceiros é oferecer apoio logístico a essa ação de âmbito nacional, fazendo com que todos os elos envolvidos na cadeia de agronegócio contribuam, de maneira efetiva, para a sustentabilidade ambiental. A parceria com uma rede de recicladores processa cerca de $90 \%$ das embalagens devolvidas e $10 \%$ estão contaminadas e como não podem ser recicladas são incineradas.

O Decreto $N^{\circ} 4074{ }^{(3)}$, de 04 de Janeiro de 2002, no Capítulo IV, Seção II, da Destinação Final de Sobras e de Embalagens, estabelece que todos os segmentos que tenham alguma relação com agrotóxicos devem contribuir para que as embalagens tenham um destino final seguro.

Os agricultores devem efetuar a devolução das embalagens vazias, com as tampas, aos estabelecimentos comerciais em que foram adquiridos, no prazo de até um ano, contado da data da compra. As embalagens rígidas, que contiveram formulações miscíveis ou dispersivas em água, devem ser submetidas pelo usuário à operação da tríplice lavagem.

Os estabelecimentos comerciais devem dispor de instalações adequadas para recebimento e armazenamento das embalagens vazias 
devolvidas, até que sejam recolhidas pelas respectivas empresas titulares do registro. Os fabricantes são responsáveis pelo recolhimento, transporte e destinação final das embalagens vazias devolvidas.

A evolução no recolhimento dos Estados entre os meses de janeiro e novembro de 2004 foi expressiva. Em Santa Catarina o índice de recolhimento aumentou 266,6\% (de 100 para 366,5 toneladas), em Minas Gerais foram devolvidos $250,5 \%$ a mais de embalagens em relação a 2003 (de 354,9 para 1.244 toneladas), em Mato Grosso foi $98,2 \%$ a mais de embalagens (passou de 1.434 para 2.842 toneladas), em São Paulo os índices de recolhimento aumentaram em $93,7 \%$ (de 1.189 para 2.304 toneladas) e o Paraná aumentou o volume devolvido em $64,5 \%$ (passou de 1.922 para 3.161 toneladas). Na Figura 3 é mostrada esta evolução do recolhimento de embalagens no Brasil desde a criação do inpEV até $2005^{(26)}$.

As embalagens recebidas podem ter dois destinos que são: a reciclagem, quando já submetidas à tríplice lavagem, e a incineração quando contaminadas.

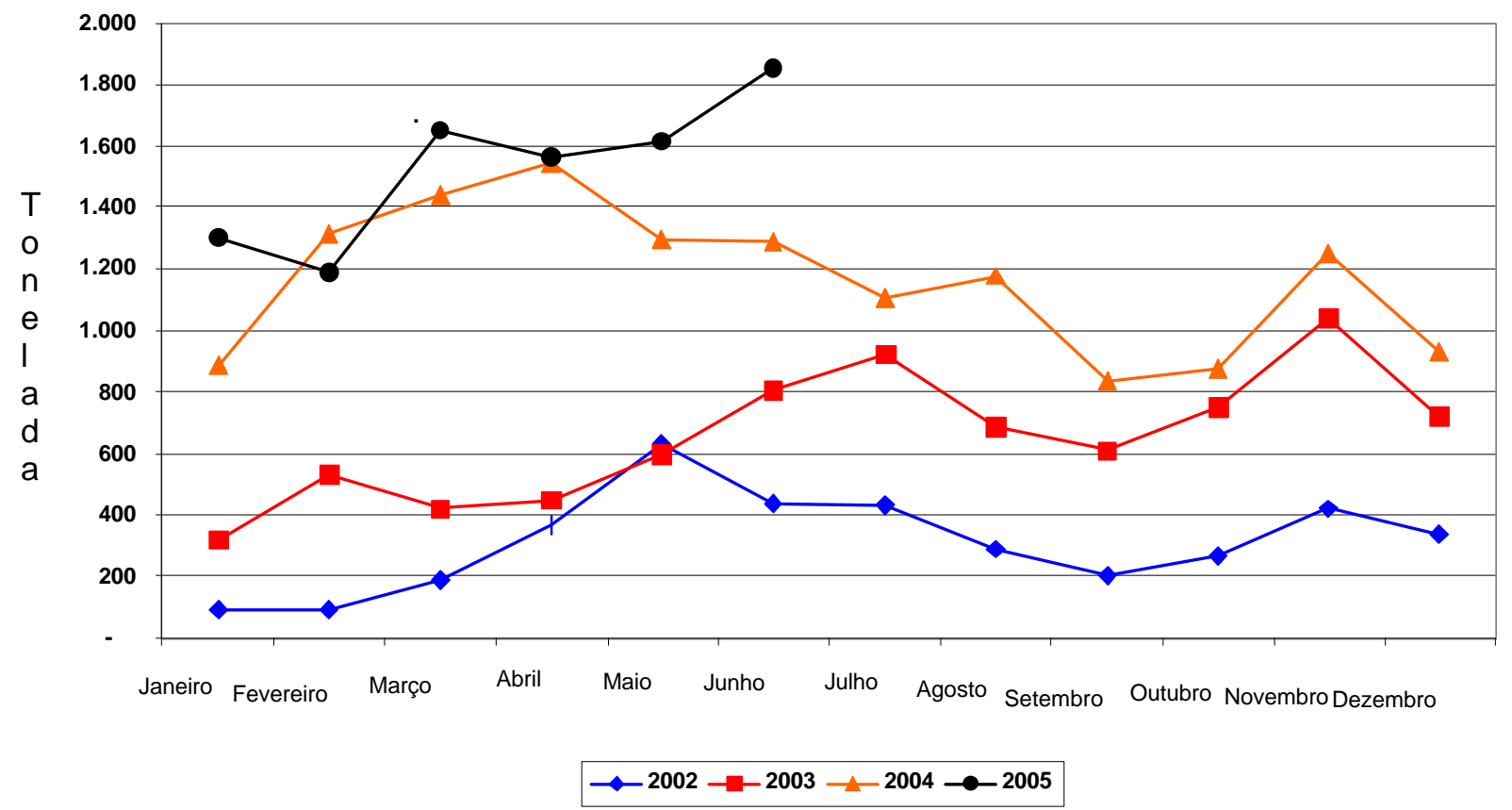

FIGURA 3. Evolução da coleta mensal de embalagens de 2002 a junho de $2005^{(26)}$. 


\subsubsection{Tipos de Embalagens}

A Lei $\mathrm{N}^{0} 7802^{(27)}$ de 11 de Julho de 1989 , Artigo $6^{\circ}$, estabelece que todas as embalagens de agrotóxicos deverão atender aos seguintes requisitos:

- devem ser projetadas e fabricadas de forma a impedir qualquer vazamento, evaporação, perda ou alteração de seu conteúdo;

- os materiais de que forem feitas devem ser insuscetíveis de ser atacados pelo conteúdo ou de formar com ele combinações nocivas ou perigosas;

- devem ser suficientemente resistentes em todas as suas partes, de forma a não sofrer enfraquecimento e a responder adequadamente às exigências de sua normal conservação.

Quanto ao tipo de formulação as embalagens foram divididas em ${ }^{(28)}$ :

- Embalagens laváveis - são as embalagens rígidas de plástico, metal ou vidro que acondicionam formulações líquidas de agrotóxicos para serem diluídas em água:

- Embalagens não laváveis - são as embalagens flexíveis de saquinhos plásticos, de papel, metalizadas ou mistas e embalagens rígidas que não utilizam água como veículo de pulverização. São as embalagens para tratamento de sementes e as formulações oleosas.

\section{Embalagens do tipo COEX}

O plástico é o melhor produto que atende a todas as exigências estabelecidas pela Lei $7802^{(27)}$ porque é um material inerte, resistente, de fácil manuseio e baixo peso facilitando o transporte quando comparado a outros materiais.

Os inseticidas contêm em suas formulações alguns solventes orgânicos e os plásticos comuns, polietileno, nylon, são permeáveis a essas substâncias. O copolímero de etileno e álcool vinílico, EVOH, é um plástico transformável e com barreiras contra aromas, óleos e solventes. 
O polietileno coextrudado, COEX, é um plástico extrudado em camadas sobrepostas de polietileno e uma camada de EVOH, PE/EVOH, desta forma estas embalagens são as mais resistentes à perda por volatilização dos agrotóxicos e consequentemente à contaminação.

\subsubsection{Tríplice Lavagem}

A tríplice lavagem é um procedimento de limpeza e aproveitamento do agrotóxico que é efetuado nas embalagens rígidas de plástico, metal ou vidro que contenham formulações líquidas de agrotóxico para serem diluídos em água, conforme especificação da norma técnica NBR $13.968^{(29)}$. Os objetivos da tríplice lavagem são: economia com o aproveitamento total do produto sem deixar restos na embalagem, segurança e proteção ambiental evitando riscos de contaminação do solo e mananciais.

Os procedimentos para a tríplice lavagem são:

- Esvaziar completamente o conteúdo da embalagem no pulverizador;

- Adicionar água limpa à embalagem até $1 / 4$ do seu volume;

- Tampar a embalagem e agitá-la por 30 segundos;

- Despejar a água de lavagem no tanque do pulverizador que será aplicado na lavoura;

- Repetir essa operação três vezes;

- Inutilizar a embalagem, perfurando o fundo.

\subsubsection{Destinação Final Segura das Embalagens}

Após serem devolvidas nos estabelecimentos comerciais, as embalagens são enviadas a um posto de recebimento onde são selecionadas em contaminadas e não contaminadas e despachadas para uma central de recebimento.

$\mathrm{Na}$ central de recebimento as embalagens são criteriosamente separadas por tipo de matéria-prima: plástico (Polietileno de alta densidade PEAD - COEX, poli(tereftalato de etileno) - PET), vidro, metal e papelão e prensadas para redução do volume. As embalagens lavadas são encaminhadas 
para reciclagem e as não lavadas e papelão são incineradas. Na Figura 4 é mostrado o esquema da devolução das embalagens de agrotóxicos.

Os plásticos são um bom exemplo de resíduos que podem ser reciclados, pois possuem um elevado valor agregado e podem ser transformados, reusados e inseridos no processo produtivo. É uma atividade lucrativa e ambientalmente correta, pode ser processado várias vezes e atualmente existem mais de 15 materiais produzidos pela reciclagem destas embalagens, como conduíte, cordas, embalagem para óleo lubrificante, tampas, madeira plástica, barricas de papelão, entre outros.

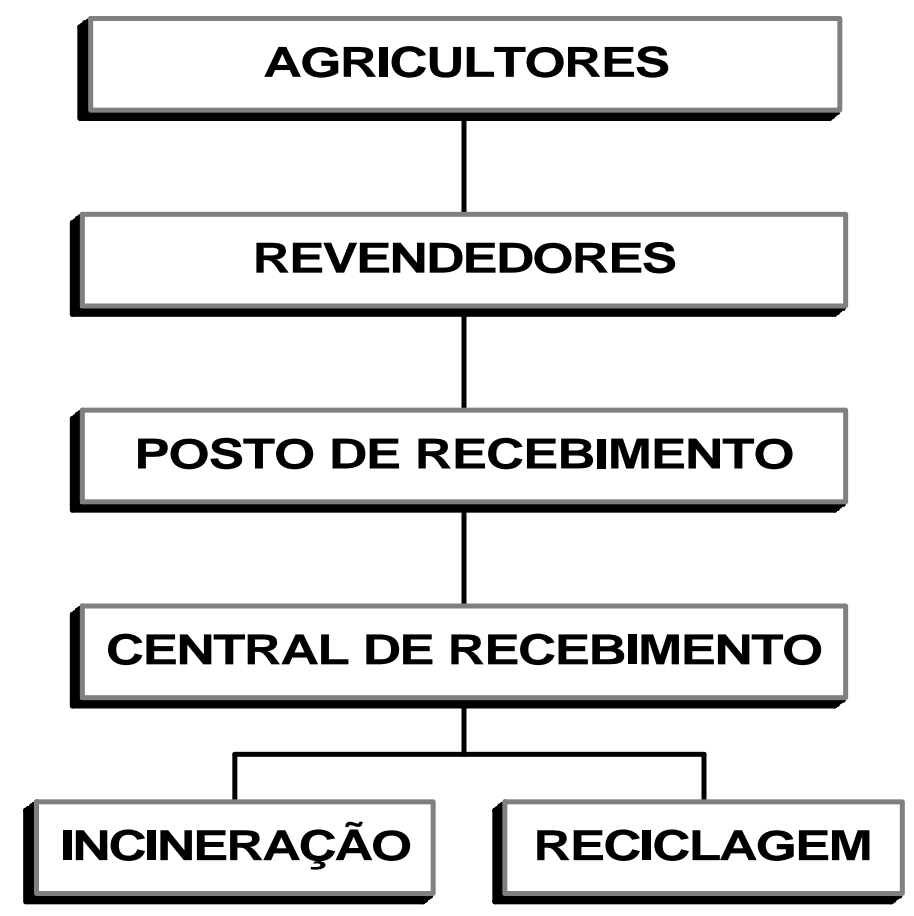

FIGURA 4. Logística da devolução das embalagens de agrotóxicos

O essencial para reciclagem do plástico é que não tenha impurezas nem resíduos e que a matéria-prima seja de boa qualidade. A tecnologia empregada pode ser ${ }^{(30)}$ :

- Primária ou pré-consumo - são os plásticos reciclados virgens, ou seja, não utilizados para consumo, são as peças defeituosas e aparas. É um material limpo e totalmente reciclável. 
- Secundário ou pós-consumo - são os plásticos de coletas seletivas e lixões constituídos pelos mais diversos tipos de materiais. Para o seu reaproveitamento é necessário separá-los e descontaminá-los.

- Terceário ou químico - são transformados em combustível ou em matéria-prima original por processos termoquímicos.

\subsection{Processos de Oxidação Avançada e suas Aplicações Ambientais.}

Os processos de oxidação avançada, POAs utilizam o alto poder de oxidação dos radicais hidroxila, ${ }^{\circ} \mathrm{OH}$, para reagir indistintamente com os compostos orgânicos. Esses processos têm sido utilizados em vários estudos para degradação de compostos orgânicos tóxicos e para recuperação ambiental. É uma alternativa para substituir outros processos de tratamento como a incineração que libera dioxina para o ambiente e resíduos sólidos que são depositados em aterros adaptados e o tratamento biológico que requer um tempo longo de digestão dos efluentes para atingir quantidades mínimas de contaminantes permitido por lei para descarga no ambiente.

Entre os POAs destacam-se o processo oxidativo fenton onde a geração de radicais hidroxila é feita pela da reação de um sal ferroso com peróxido de hidrogênio; pela sonólise causada pela ação do som de uma freqüência extremamente alta sobre água líquida criando bolhas em seu interior, essas cavidades ao contraírem o seu interior é aquecido adiabaticamente atingindo milhares de graus e o vapor da água sofre uma termólise gerando radicais hidroxila e pelas radiações ionizantes que produzem os radicais hidroxila pela radiólise na água.

$\mathrm{Na}$ Tabela 6 são apresentados os potenciais de oxidação de alguns agentes oxidantes utilizados no tratamento de águas de abastecimento e oxidação de compostos tóxicos ${ }^{(31)}$.

\subsubsection{Uso da Tecnologia Nuclear na Recuperação Ambiental}

A tecnologia nuclear tem sido usada na proteção e conservação do meio ambiente, seu emprego na destruição de compostos orgânicos tóxicos 
presentes em amostras ambientais, água potável, remediação de solos e efluentes industriais têm sido objeto de estudo de vários autores no Brasil e no mundo.

TABELA 6. Potencial de oxidação de alguns elementos, compostos e radicais lívres ${ }^{(31)}$.

\begin{tabular}{l|c}
\hline \multicolumn{1}{c|}{ Espécie } & Potencial de Oxidação (V) \\
\hline Flúor & 3,03 \\
Radical Hidroxila & 2,80 \\
Ozônio & 2,07 \\
Peróxido de Hidrogênio & 1,78 \\
Permanganato & 1,68 \\
Ácido Hipobromoso & 1,59 \\
Dióxido de Cloro & 1,57 \\
Ácido Hipocloroso & 1,49 \\
Cloro & 1,36 \\
Bromo & 1,09 \\
lodo & 0,54 \\
\hline
\end{tabular}

O processo de transferência de energia das partículas carregadas para os átomos das moléculas se dá por um grande número de colisões. Um fóton de raio gama ao atravessar a matéria pode ser absorvido por um átomo ou ser desviado de sua trajetória.

As principais fontes industriais de raios gama são as de cobalto-60 e as de césio-137. Ambas são produzidas artificialmente, o cobalto 60 é obtido quando o cobalto 59 é bombardeado com neutrons em um reator nuclear pela reação $(n, \gamma)$. O césio 137 é obtido na forma de cloreto de césio extraído no reprocessamento de combustível queimado em reatores nucleares. O cobalto 60 ao desintegrar emite dois raios gama com as energias de 1,17 MeV e 1,33 MeV. Sua meia-vida é de 5,27 anos. 


\subsubsection{Radiólise da água}

A radiólise da água fornece radicais e íons para reagir com solutos que podem ser hidrocarbonetos, álcoois, aldeídos, ácidos carboxílicos e praticamente todos os compostos orgânicos.

$\mathrm{Na}$ interação da radiação gama com uma molécula de água será formado espécies ionizadas e excitadas ${ }^{(32)}$.

$\mathrm{Na}$ ionização forma um íon positivo e um elétron.

$$
\mathrm{H}_{2} \mathrm{O} \longrightarrow \mathrm{H}_{2} \mathrm{O}^{+}+\mathrm{e}^{-}
$$

$\mathrm{O}$ íon positivo reage com a água formando um radical hidroxila e $\mathrm{H}_{3} \mathrm{O}^{+}$

$$
\mathrm{H}_{2} \mathrm{O}+\mathrm{H}_{2} \mathrm{O}^{+} \longrightarrow \mathrm{OH}+\mathrm{H}_{3} \mathrm{O}^{+}
$$

O elétron sofre uma termalização ou seja, é capturado pela água, resultando em um elétron aquoso.

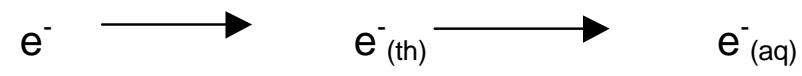

A molécula excitada dissocia-se com a formação de hidrogênio atômico e radical hidroxila.

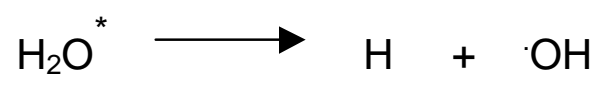

$\mathrm{Na}$ Figura 5 são mostradas as duas vias de formação dos radicais primários da radiólise da água: excitação e ionização, que ocorrem simultaneamente.

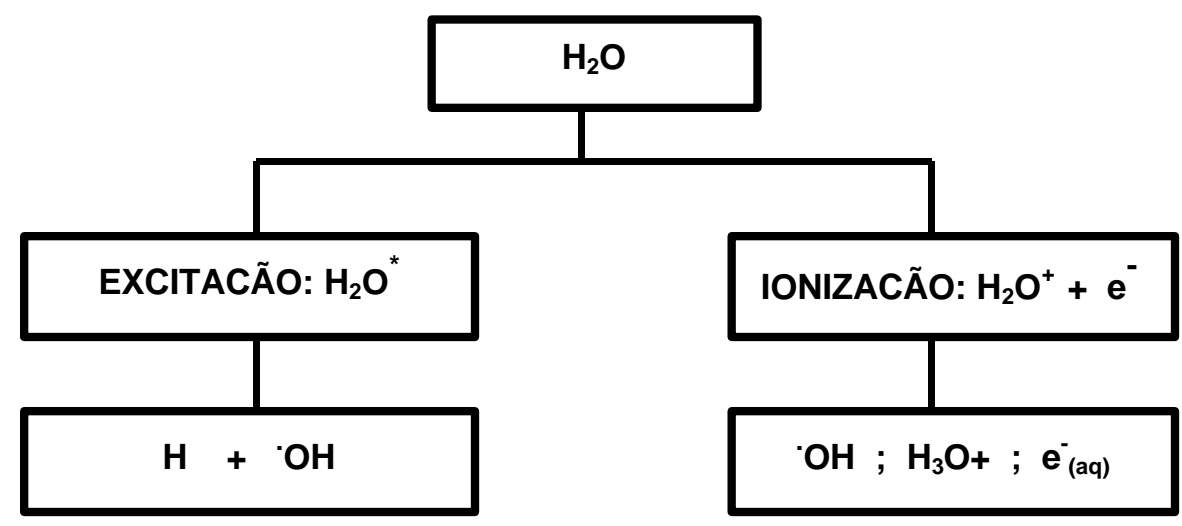

FIGURA 5. Formação dos produtos primários da radiólise da água. 
radicais $^{(32)}$.

Esses radicais poderão reagir entre si com formação de outros

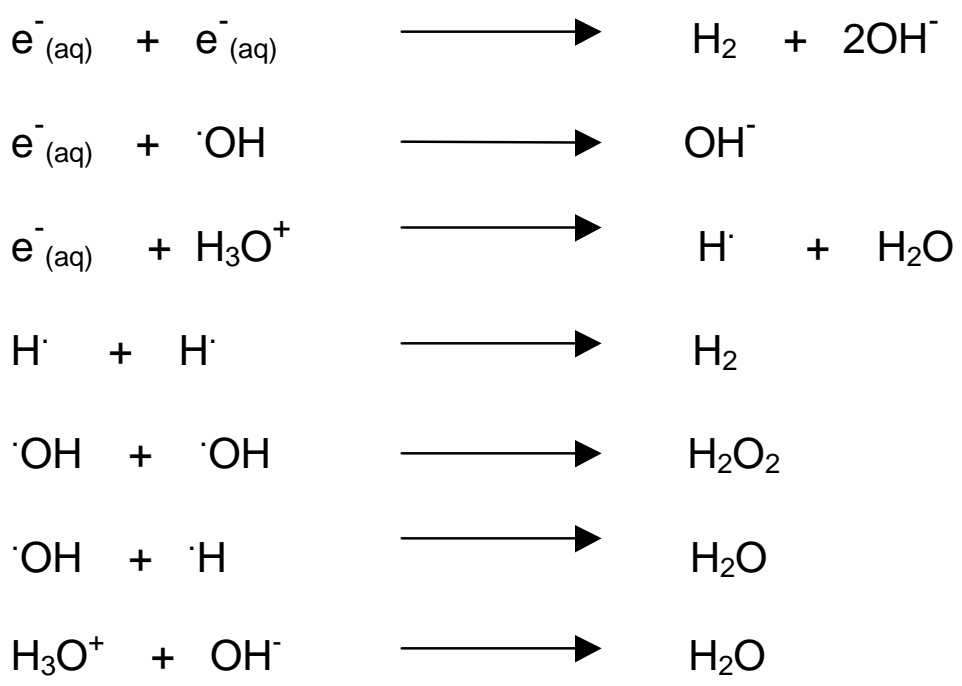

Pikaev e Shubin ${ }^{(33)}$ propuseram um estudo para melhorar ou substituir os métodos tradicionais de purificação de água para abastecimento público e de tratamento de efluentes industriais usando as radiações ionizantes por raios gama de Co-60 e acelerador de elétrons. Os principais parâmetros controlados para águas de abastecimento são a cor pela presença de ácidos húmico e fúlvico, odor e microrganismos. Uma dose de $4 \mathrm{kGy}$ foi suficiente para a remoção de 20 graus da cor inicial da água para abastecimento da cidade de Moscou. Essa dose foi diminuída para 0,8 kGy borbulhando ar durante a irradiação. Foi verificado uma redução de 99,93\% no número de microorganismos por $\mathrm{cm}^{3}$ com uma dose de 1 kGy. Nestas condições a água pode ser usada para beber e para higienização. Para efluentes industriais a solução é mais complexa e depende do tipo de contaminação e da concentração. A remoção da cor de efluentes de indústria de tecelagem por radiólise é realizada pelo ataque dos radicais ao grupo cromóforo e a taxa de degradação é específica para diferentes tipos de corantes.

Sakumoto e Miyata ${ }^{(34)}$ propuseram um estudo para a degradação de compostos orgânicos poluentes usando uma combinação de radiação com oxidação biológica, coagulação e ozonização para a redução da dose de degradação. O uso combinado da radiação ionizante com oxidação biológica incrementa a remoção do carbono orgânico de uma solução aquosa oxigenada de etileno glicol. A radiação ionizante é capaz de converter compostos de difícil biodegradabilidade em compostos intermediários. O uso combinado da radiação e 
oxidação biológica reduz em 15 vezes a dose necessária para a mineralização do etileno glicol. Outra técnica é o uso da radiação e coagulação. O uso simultâneo de radiação e ozônio é muito superior aos outros métodos aplicados e pode ser usado independentemente do tipo de composto orgânico. O ozônio é um poderoso agente oxidante, contudo sua ação na degradação de moléculas orgânicas é limitada porque a oxidação com ozônio ocorre principalmente nas regiões insaturadas das moléculas.

A degradação da bifenila policlorada, PCB, diluído em isooctano e ozônio foi estudada por Mincher e colaboradores ${ }^{(35)}$ com o objetivo de desenvolver um método seguro e eficiente para descarte deste composto. Foi comparado o grau de degradação por radiação gama do PCB diluído em isooctano com e sem ozônio. Na solução com ozônio não há nenhum avanço significativo na degradação do PCB até 100 kGy. Na solução sem ozônio com uma dose de 40 kGy o PCB não foi detectado. A conclusão dos autores foi que o ozônio captura um elétron e forma um radical hidroxila que é capturado pelo isooctano e a degradação do PCB é por captura de elétron e não pelo ataque do radical hidroxila .

Solpan e Guven ${ }^{(36)}$ estudaram a degradação por radiação gama de dois corantes, "Reactive Blue" (RB5) e "Reactive Black" (RB15), com e sem adição de peróxido de hidrogênio, $\mathrm{H}_{2} \mathrm{O}_{2}$. A degradação dos corantes foi confirmada pela descoloração das soluções por espectrometria de UV visível. A descoloração com adição de peróxido de hidrogênio foi mais eficiente nos dois corantes porque o peróxido de hidrogênio reage com um elétron hidratado originando um radical hidroxila melhorando a degradação dos corantes sugerindo que a destruição do cromoforo foi realizada pelo ataque do radical hidroxila. Todos os corantes foram irradiados com diferentes concentrações. Os resultados mostraram que a descoloração do corante RB5 foi mais eficiente do que o corante RB15. Este fato pode ser atribuído a diferença na estrutura dos corantes. O grupo $(-\mathrm{N}=\mathrm{N}-)$, presente na estrutura do RB5, é mais sensível a radiação e rompe imediatamente mesmo quando exposto a taxas de dose baixas.

Taixing e colaboradores ${ }^{(37)}$ estudaram o mecanismo de degradação do metil t-butil éter (MTBE) pelo ataque dos radicais hidroxila em uma solução de 100 ppm saturada com $\mathrm{N}_{2} \mathrm{O} / \mathrm{O}_{2}$ na proporção de 4:1. Nestas condições o elétron hidratado é capturado pelo $\mathrm{N}_{2} \mathrm{O}$, reage com uma molécula de água e converte-a 
em radical hidroxila. A degradação total do $M T B E$ foi atingida com uma dose de 6,3 kGy. Os principais produtos de degradação foram o formato de t-butila, álcool t-butilico e acetato de metila.

Durante o refino de petróleo são gerados efluentes com altos teores de contaminantes como metais pesados, sulfeto, amônia, compostos orgânicos e salinidade. Tratamentos convencionais como filtração, flotação, troca ionica e absorção em carvão ativado não têm um rendimento conveniente porque a salinidade diminui a eficiência do tratamento.

Duarte e colaboradores ${ }^{38}$ apresentaram um estudo sobre a degradação destes efluentes oriundos de duas refinarias de petróleo irradiando-os em um acelerador de elétrons. Estes efluentes apresentavam uma alta concentração de compostos orgânicos como benzeno, tolueno, xileno e etilbenzeno e foram irradiados com as doses de 20 kGy; 50 kGy e 100 kGy. Embora a dose para a redução de $90 \%$ de todos os compostos orgânicos seja alta, 100 kGy, este processo pode ser muito promissor no futuro porque a alta complexidade destes efluentes torna difícil e dispendioso seu tratamento por métodos convencionais, concluíram os autores.

As reações fotocatalisadas com dióxido de titânio, $\mathrm{TiO}_{2}$ são uma alternativa para o tratamento de efluentes com baixas concentrações de poluentes. Chitose e colaboradores ${ }^{(39)}$ mencionaram que a desvantagem do uso desta técnica é que a penetração dos raios ultravioleta na solução é de curto alcance e isto dificulta a construção de reatores com grandes dimensões. Uma solução aquosa de fenol contendo nanopartículas de $\mathrm{TiO}_{2}$ com $30 \mathrm{~nm}$ de diâmetro, foi irradiada com raios gama, elétron e ultravioleta.

A dose de radiação necessária para a degradação do fenol foi menor para a radiação gama e elétron do que o ultravioleta. $\mathrm{A}$ adição de $\mathrm{TiO}_{2}$ não teve nenhum efeito sobre a taxa de degradação do fenol mas foi significativa para a remoção do carbono orgânico sugerindo que este composto tem efeito sobre a degradação dos produtos de radiólise do fenol. Contudo os autores evidenciam que o presente estudo sobre o efeito das nanopartículas não é suficiente para esclarecer a influência do $\mathrm{TiO}_{2}$ sobre a degradação do fenol. Outras nanopartículas devem ser investigadas no futuro.

O álcool polivinílico, PVA, é um polímero solúvel em água e amplamente utilizado como adesivo e material de cobertura para 
impermeabilização. A produção mundial é de 650.000 toneladas por ano e a descarga de efluentes de polimerização sem tratamento vem originando sérios problemas de poluição ambiental porque técnicas convencionais de degradação não são eficientes. A degradação biológica é limitada com eficiência de $40 \%$ após 48 dias de incubação em reatores e formação de muita espuma.

Zhang e $\mathrm{Yu}^{(40)}$ estudaram um método alternativo para a degradação do PVA usando a radiação do cobalto 60 experimentando as variações de concentração, taxa de dose, $\mathrm{pH}$ e adição de peróxido de hidrogênio, $\mathrm{H}_{2} \mathrm{O}_{2}$. Nestas condições o PVA foi totalmente mineralizado, porém, é dependente da concentração inicial sendo favorecida em meio ácido ou básico e a adição de $\mathrm{H}_{2} \mathrm{O}_{2}$ facilita a degradação.

Na queima de combustíveis fósseis, carvão, óleo e gás natural, são gerados um grande número de hidrocarbonetos policíclicos e poliaromáticos. Estes compostos são tóxicos mesmo em baixas concentrações. Um destes compostos é o fluoranteno que pode ser transportado pelo vento e precipitado pela chuva e neve contaminando o solo e os lençóis de água subterrânea.

Popov e Getoff ${ }^{(41)}$ e Wasiewicz e colaboradores ${ }^{(42)}$ usaram a radiação ionizante do cobalto 60 para degradar uma solução aquosa de fluoranteno e 2,3dihidroxinaftaleno como uma alternativa para eliminar a emissão destes poluentes dos gases gerados pela queima de óleo combustível nas indústrias antes de lançá-los na atmosfera. Os resultados foram satisfatórios porque o fluoranteno e o 2,3-dihidroxinaftaleno podem ser decompostos pela radiação com uma dose absorvida relativamente baixa.

\subsubsection{Aplicação da Radiação lonizante na Degradação de Agrotóxicos}

A irradiação de grãos é uma técnica moderna usada para desinfestar grãos, porém, após a irradiação persiste o problema da reinfestação. O inseticida usado para controlar a reinfestação é o malathion por ser pouco letal a animais de sangue quente. Wiendl e Sgrillo ${ }^{(43)}$ propuseram um trabalho para verificar a degradação do malathion depositado em papel de filtro e irradiados com as doses de 10 kGy e 20 kGy. Os resultados da irradiação foram confirmados colocando 
10 insetos adultos em cada amostra e a cada 24 horas era anotado o número de insetos mortos.

Os resultados confirmaram a degradação do inseticida por radiação gama verificado pela longevidade dos insetos que permaneceram nos papéis irradiados. Os autores concluíram que o inseticida irradiado com as doses de 10 kGy e $20 \mathrm{kGy}$ com a concentração de $37,5 \mathrm{mg} / \mathrm{m}^{2}$ praticamente não perde seu efeito letal. Os grãos armazenados não são irradiados com dose acima de 1 kGy, portanto, esta técnica nunca poderá ser usada comercialmente para a degradação do inseticida em grãos armazenados.

Javaroni e colaboradores ${ }^{(44)}$ determinaram a taxa de degradação do lindano, isomero tóxico do benzeno hexaclorado, $\mathrm{BHC}$, persistente no ambiente e inerte aos ataques de ácidos e bases, quando submetido a uma dose de radiação gama. Segundo os dados obtidos por cromatografia o lindano, não obstante, pertencer a classe dos inseticidas mais persistentes não resiste aos efeitos da radiação gama. Concluem os autores que a radiação ionizante poderá ser utilizada como um meio de descontaminação ambiental.

Yongke e colaboradores ${ }^{(45)}$ propuseram um estudo sobre a degradação radiolítica do benzeno hexaclorado, $\mathrm{BHC}$, em uma solução alcalina de etanol. A degradação é efetivada por uma perda de cloro da molécula fato confirmado por análise dos produtos de degradação por cromatografia combinado com espectrometro de massa, CG/MS. Benzeno pentaclorado foi o principal produto de degradação detectado. Por esse estudo os autores sugeriram que solos contaminados quando misturados com etanol e posteriormente irradiados com raios gama o benzeno hexaclorado pode ser transferido para a solução e ser parcialmente degradado.

Landgraf e colaboradores ${ }^{(46)}$ determinaram os efeitos de diferentes taxas de doses e de doses totais de radiação gama na degradação do paration utilizando o inseticida radiomarcado com C-14 e na concentração de $10 \mathrm{mg} / \mathrm{l}$. Com uma taxa de dose de 3,41 kGy/h e dose de 0,75 kGy todos os fragmentos marcados com C-14 da molécula foram recuperados ou permaneceram na solução irradiada. Nestas condições não houve formação de produtos voláteis. Para uma dose fixa e aumentando gradativamente a taxa de dose a formação de produtos hidrossolúveis também aumenta. As análises efetuadas por GC/MS indicaram a formação de paraoxon, amino-paration e p-nitrofenol. Com uma dose 
de 1 kGy $98 \%$ do inseticida foi degradado. Analogamente ao paration, $90 \%$ do paraoxon que é mais tóxico também foi degradado.

Luchini e colaboradores ${ }^{(47)}$ irradiaram o paration diluído em metanol. Com uma dose de $30 \mathrm{kGy} 99 \%$ do inseticida foi degradado e os produtos foram idênticos aos produtos de degradação em meio aquoso identificados por Landgraf e colaboradores ${ }^{(46)}$.

Vel Leitner e colaboradores ${ }^{(48)}$ estudaram a degradação da atrazina em água contendo substâncias húmicas por meio de radiação gama borbulhando nitrogênio, oxigênio, $\mathrm{N}_{2} \mathrm{O}$ e uma mistura gasosa de $\mathrm{N}_{2} \mathrm{O} / \mathrm{O}_{2}$. Existe uma diferença predominante na formação de radicais quando se borbulha tipos diferentes de gases. Borbulhando nitrogênio há predominância na formação de elétron aquoso, borbulhando a mistura gasosa de $\mathrm{N}_{2} \mathrm{O} / \mathrm{O}_{2}$ há predominância de formação de radicais hidroxila. $\mathrm{A}$ degradação da atrazina é realizada pela ação do radical hidroxila e pelo elétron solvatado. A degradação foi mais eficiente borbulhando nitrogênio. Para o tratamento de águas naturais borbulhar nitrogênio não é a melhor solução. Águas naturais contêm nitrato que capturam elétrons diminuindo a eficiência do sistema de irradiação.

Angelini e colaboradores ${ }^{(49)}$ estudaram a degradação radiolítica da atrazina com uma concentração próxima a encontrada no ambiente. Em solução a degradação é causada pela ruptura da ligação carbono-cloro e o halogênio é substituído por um radical hidroxila estabilizando a estrutura aromática. $A$ atrazina foi completamente degradada com uma dose de 0,1 kGy, porém, alguns produtos da radiólise resistiram a dose de 50 kGy.

Abdel e colaboradores ${ }^{(50)}$ investigaram a degradação de dois inseticidas, pertencentes a dois grupos químicos, em solução aquosa por radiação gama e acelerador de elétrons. $O$ lannate pertence ao grupo tiuréia e o fenvalerato ao grupo fenilacetato. A degradação do lannate foi maior do que a degradação do fenvalerato nos dois sistemas de irradiação. Essa diferença de comportamento é explicada pela diferença das estruturas químicas dos inseticidas. O lannate é um composto alifático e o fenvalerato possui três anéis aromáticos. Compostos alifáticos são mais sensíveis a radiação e o benzeno mais resistente, porém, a taxa de degradação no acelerador foi maior do que no irradiador gama para os dois compostos. 
O ácido 2,4-D, ácido 2,4-diclorofenol acético é um herbicida utilizado no controle de uma grande variedade de ervas daninhas. Tem alta solubilidade em água e após aplicação atinge as águas dos lençóis subterrâneos pela ação das águas da chuva e irrigação. Zona e Solar ${ }^{(51,52)}$ estudaram a degradação do ácido 2,4-D e a influência da concentração de oxigênio na mineralização dos produtos intermediários com radiação gama, com uma dose de 4 kGy ocorreu a degradação total de $100 \mathrm{mg} / \mathrm{L}$ do herbicida. Os produtos intermediários encontrados foram os ácidos 2-cloro-4-hidroxi e 4-cloro-2-hidroxi fenoxiacético. Injetando-se oxigênio na solução durante irradiação os produtos intermediários são degradados, com a mesma dose necessária para a degradação do ácido 2,4D, formando ácido acético como principal produto.

\subsection{Métodos de Detecção de Agrotóxicos}

As técnicas analíticas mais adequadas para detecção dos agrotóxicos são as cromatográficas, sendo a cromatografia gasosa, CG, a mais frequentemente usada. Colunas capilares com performance alta contendo fases estacionárias não-polar ou semi-polar, principalmente com base de polisiloxano, são as mais utilizadas. Atualmente a CG associada com espectrometria de massa (CG/MS) ou com tandem MS (CG/MS-MS) é frequentemente empregada para análise de mistura de agrotóxicos. No caso de confirmação de agrotóxicos específicos, são utilizados os detectores de captura de elétrons (DCE), nitrogêniofósforo (DNF) e ionização de chama (DIC).

De acordo com o tipo do agrotóxico utiliza-se um tipo diferente de coluna, para os organoclorados utiliza-se a coluna capilar de sílica fundida com dimensões variando entre 10 e 60 metros, diâmetro interno entre 0,1 a 0,53 mm e com filme de 0,3 $\mu \mathrm{m}$ de espessura da fase estacionária apolar. Estas colunas possuem nomes comerciais diferentes de acordo com o fabricante, como exemplos pode-se citar as do tipo DB1, OV1, SE30, HP1, CPSIL 5CB, e OV11 (100\% dimetil polissiloxano).

Para os orfanofosforados utiliza-se a coluna capilar de sílica fundida com dimensões entre 10 e $60 \mathrm{~m}$, diâmetro interno de 0,1 a 0,53 mm e com filme 
de $0,5 \mu \mathrm{m}$ de espessura da fase estacionária semi polar iguais as do tipo OV17, DB17, HP17, SPB50 e CPSIL 24CB (fenil metil polissiloxano - 50\% fenil).

Vários métodos foram desenvolvidos para determinar diferentes grupos de inseticidas usando diferentes solventes para extração em diferentes substratos:

- Pang e colaboradores $^{(53)}$ desenvolveram um método para determinação de multiresíduos de inseticidas piretróides em vegetais e frutas usando acetonitrila para extração.

- Fernandez-Alba e colaboradores ${ }^{(54)}$ descreveram um método para monitorar inseticidas e fungicidas e seus metabolitos em águas subterrâneas.

- Stan e Linkerhagner ${ }^{(55)}$ desenvolveram um método para análise residual de inseticidas com diferentes heteroátomos na estrutura química: nitrogênio, cloro, enxofre, fósforo, flúor e bromo.

- Bernal e colaboradores ${ }^{(56)}$ desenvolveram um método para análise multiresidual de inseticidas e herbicidas em solos.

- Miyahara e colaboradores ${ }^{(57)}$ desenvolveram um método analítico multiresidual para determinar dez inseticidas organofosforados em alimentos.

- Hatrik e Tekel ${ }^{(58)}$ descreveram um método para determinação de herbicidas, inseticidas e fungicidas e seus produtos de degradação em água, e apresentaram as vantagens e desvantagens do uso da cromatografia gasosa e as etapas de uma pré-análise: extração líquido-líquido, líquido-sólido, purificação e concentração.

- Lee e Wylie ${ }^{(59)}$ fizeram uma comparação entre o detetor de emissão atômica, AED, e outros tipos de detetores, nitrogeniofósforo, NPD, e detetor fotométrico de chama, FPD, na análise de resíduos de 12 inseticidas organoclorados e organofosforados em 
vegetais e frutas. Destacaram que o AED é mais seletivo, porém, é o que tem maior interferência.

- Bavcon e colaboradores ${ }^{(60)}$ descreveram um método para determinação do diazinon e malation e seus produtos de degradação em várias matrizes usando um detetor de ionização de chama, DIC.

- Jin e Webster ${ }^{(61)}$ descreveram um método para determinação do clorpirifós e seus metabolitos em amostras de solo.

- Chuang e colaboradores ${ }^{(62)}$ usaram a espectrometria de massa para a identificação do principal produto de degradação do clorpirifós em múltiplas amostras.

- Vidal e colaboradores ${ }^{(63)}$ e Aguilar e colaboradores ${ }^{(64)}$ identificaram vários agrotóxicos por espectrometria de massa em amostras de água.

\subsection{Objetivo}

O objetivo deste trabalho é a descontaminação de embalagens do inseticida e acaricida clorpirifós, utilizando a radiação ionizante, para evitar a contaminação ambiental e para possibilitar a reciclagem ou o destino final seguro destas embalagens. Para atingir este objetivo as seguintes etapas foram realizadas:

- Implantação de técnica analítica para o clorpirifós;

- Estudo da degradação do clorpirifós e a formação de subprodutos e

- Estudo dos sistemas de irradiação destas embalagens. 


\subsection{MATERIAIS E MÉTODOS}

O trabalho envolveu três fases de ação, que foram o contaminante a ser estudado, a matriz a ser tratada e o processamento por irradiação.

Em função da quantidade utilizada na agricultura optou-se por estudar o inseticida e acaricida clorpirifós. Na primeira etapa os ensaios preliminares concentraram-se nos estudos do solvente e da técnica analítica mais adequada para a quantificação do clorpirifós e na análise qualitativa dos produtos de degradação.

\subsection{Técnicas Analíticas}

Para a análise qualitativa dos produtos formados pela degradação após irradiação foi utilizado um espectrometro de massa associado a um cromatógrafo a gás, CG-MS, modelo QP500 da Shimadzu com as seguintes condições:

- coluna capilar de sílica fundida DB5 (5\% fenil-95\% dimetil polissiloxano) apolar da J \& W Scientific, Folson, CA, USA, com $30 \mathrm{~m}$ de comprimento e $0,32 \mathrm{~mm}$ de diâmetro interno e com filme de $0,25 \mu \mathrm{m}$ de espessura da fase estacionária;

- hélio com grau de pureza 5.0 analítico como gás de arraste e pressão de 100kPa;

- operação do detetor de massa em modo impacto de elétron (EI), usando $1,50 \mathrm{kV}$ de voltagem de ionização e temperatura de $250^{\circ} \mathrm{C}$;

- temperatura da interface CG-MS ajustada para $240^{\circ} \mathrm{C}$;

- volume de injeção de $1 \mu \mathrm{L}$.

Para a análise quantitativa do clorpirifós antes e após irradiação foi utilizado um cromatógrafo a gás CG17A da Shimadzu com detector de ionização de chama, DIC, com os parâmetros ajustados para os seguintes valores:

- Coluna capilar de silica fundida DB5 (5\% fenil-95\% dimetil polixiloxano) apolar da J \& W Scientific, Folson, CA, USA, com $30 \mathrm{~m}$ de comprimento e $0,32 \mathrm{~mm}$ de diâmetro interno e com filme de $0,25 \mu \mathrm{m}$ de espessura da fase estacionária;

- Detector de ionização de chama - DIC;

- Temperatura do detector $300^{\circ} \mathrm{C}$; 
- Temperatura do injetor $250^{\circ} \mathrm{C}$;

- Rampa de subida da temperatura da coluna:

- $50^{\circ} \mathrm{C}$ por 3,0 min.;

- $50^{\circ} \mathrm{C}-170^{\circ} \mathrm{C}\left(20^{\circ} \mathrm{C} \times \mathrm{min}^{-1}\right)$ por $1,5 \mathrm{~min}$;

- $170^{\circ} \mathrm{C}-290^{\circ} \mathrm{C}\left(10^{\circ} \mathrm{C} \times \min ^{-1}\right)$ por $1,0 \mathrm{~min}$;

- Tempo total de cada análise $21 \mathrm{~min}$;

- Volume de injeção de $1 \mu \mathrm{L}$.

\subsection{Sistemas de Irradiação}

As irradiações foram realizadas à temperatura ambiente, utilizando-se as seguintes fontes de ${ }^{60} \mathrm{Co}$ do Centro de Tecnologia das Radiações (CTR):

- Tipo "Gammacell" com taxa de dose de 4,5 kGy/h. Nessa fonte foram irradiadas o clorpirifós diluído em acetonitrila, em solução variando as proporções de água/acetonitrila e as embalagens picadas. Essa fonte é periodicamente calibrada com o objetivo de determinar com exatidão a dose absorvida pelo sistema utilizando dosímetros de Fricke e de Alanina sob a responsabilidade do grupo de dosimetria do CTR.

- As embalagens inteiras foram irradiadas no Irradiador Multipropósito do CTR com capacidade total licenciada (CNEN - Comissão Nacional de Energia Nuclear): 37 PBq (1 milhão de Curies) e atividade inicial de operação: 3,7 PBq (100 kCi). A dosimetria da câmara de irradiação foi realizada pela equipe de dosimetria com dosímetros do tipo red perpex.

\subsection{Ensaio com o Clorpirifós em Solução}

Foi utilizado um produto comercial de um concentrado emulsionável de clorpirifós com a concentração de $480 \mathrm{~g} \cdot \mathrm{L}^{-1}$ e uma emulsão concentrada com 450 g. $\mathrm{L}^{-1}$. Na Tabela 7 são apresentadas as características das formulações comerciais usadas neste trabalho de pesquisa.

TABELA 7. Características do Clorpirifós Comercial ${ }^{(65)}$ 


\begin{tabular}{ccccc}
\hline Identificação & $\begin{array}{c}\text { Produto } \\
\text { Comercial }\end{array}$ & $\begin{array}{c}\text { Classe e Grupo } \\
\text { Químico }\end{array}$ & $\begin{array}{c}\text { Concentração } \\
\left(\mathbf{g} \cdot \mathbf{L}^{-\mathbf{1}} \mathbf{)}\right.\end{array}$ & $\begin{array}{c}\text { Viscosidade } \\
\mathbf{c P} \mathbf{~ a ~ 2 0} \mathbf{0} \mathbf{C}\end{array}$ \\
\hline $\mathrm{A}$ & $\begin{array}{c}\text { Concentrado } \\
\text { emulsionável }\end{array}$ & $\begin{array}{c}\text { Inseticida } \\
\text { organofosforado }\end{array}$ & 480 & 10 \\
$\mathrm{~B}$ & $\begin{array}{c}\text { Emulsão } \\
\text { concentrada }\end{array}$ & $\begin{array}{c}\text { Inseticida } \\
\text { organofosforado }\end{array}$ & 450 & 364 \\
\hline
\end{tabular}

O principal problema encontrado na realização dos ensaios foi a baixa solubilidade do clorpirifós em água $\left(5,7 \mu \mathrm{mol} . \mathrm{L}^{-1}\right)$, sendo necessário portanto, uma avaliação do solvente que ao mesmo tempo apresentasse uma boa dissolução e fosse adequado à análise cromatográfica. A solubilidade do clorpirifós em água pode ser aumentada adicionando-se metanol ${ }^{(66)}$. A adição de metanol atua como um co-solvente auxiliando a solubilidade, isto pode ser atribuído a alta afinidade do clorpirifós por matéria orgânica.

\subsubsection{Preparação das Amostras de Clorpirifós por Diluição em Acetonitrila.}

Foi preparada uma solução estoque de 1026,8 $\mu \mathrm{mol} . \mathrm{L}^{-1}$ diluída em metanol. Porém, foi necessário determinar um solvente onde o clorpirifós apresentasse uma solubilidade alta e fosse adequado à análise cromatográfica. $\mathrm{O}$ solvente que apresentou os melhores resultados foi a acetonitrila. Desta forma todos os ensaios com clorpirifós foram realizados em acetonitrila. Preparam-se soluções por diluição da solução estoque em acetonitrila com as seguintes concentrações: $13,7 \mu \mathrm{mol} . \mathrm{L}^{-1} ; 27,4 \mu \mathrm{mol} . \mathrm{L}^{-1} ; 68,5 \mu \mathrm{mol}^{\mathrm{L}} \mathrm{L}^{-1} ; 136,9 \mu \mathrm{mol} . \mathrm{L}^{-1} \mathrm{e}$ $273,8 \mu \mathrm{mol} . \mathrm{L}^{-1}$.

\subsubsection{Preparação das Amostras de Clorpirifós por Diluição em Acetonitrila e Água.}

A presença de água é fundamental para a formação de radicais livres e conseqüente ação na degradação do inseticida. Desta forma estudou-se a proporção de água/acetonitrila que aumentasse o efeito da radiação, mas não causasse a precipitação do clorpirifós. Para tanto foram preparadas duas 
soluções estoques de clorpirifós em acetonitrila com as concentrações de 800 $\mu \mathrm{mol} . \mathrm{L}^{-1}$ e $1600 \mu \mathrm{mol} . \mathrm{L}^{-1}$. Essas soluções foram diluídas com as seguintes proporções de água/acetonitrila: 1:9, 2:8, 3:7, 4:6, 5:5, 6:4, 7:3, 8:2 e 9:1.

\subsection{Ensaios com as Embalagens Contaminadas com Clorpirifós}

Para obtenção das embalagens para estudo, o contato pessoal com o inpEV foi extremamente importante e possibilitou a visita ao Centro de Recolhimento de Embalagens de Piracicaba, situado na Rodovia do Açúcar, Km 157, Piracicaba, SP e mantido pela Cooperativa dos Plantadores de Cana do Estado de São Paulo, COPLACANA. As fotos mostradas na Figura 6, podem dar uma idéia do volume e de como é feito o acondicionamento das embalagens recebidas. As embalagens são prensadas e amarradas em fardos para facilitar 0 transporte e a armazenagem.

As embalagens tipo PEAD são mais difíceis de serem descontaminadas porque este material é permeável ao oxigênio e solventes, assim o agrotóxico penetra nas camadas da embalagem. Segundo os fabricantes, estas embalagens estão sendo substituídas pelas do tipo COEX.

Em virtude da dificuldade de encontrar embalagens contaminadas de clorpirifós na central de recolhimento de Piracicaba, pois, o volume recolhido é muito grande formando uma só quantidade de embalagens de herbicidas, fungicidas e inseticidas dificultando a seleção. Então optou-se por contatar o fabricante e obter embalagens sem uso adquirindo-se 100 embalagens do tipo coex de 85 gramas, capacidade de um litro e na cor branca. Os experimentos foram realizados utilizando-se embalagens contaminadas no laboratório com clorpirifós inteiras e cortadas em tiras. 
FIGURA 6. Embalagens descartadas de agrotóxicos no Centro de Recolhimento de Embalagens de Piracicaba.

\subsubsection{Ensaios com Embalagens Inteiras}


As embalagens contaminadas artificialmente com um concentrado emulsionável de clorpirifós foram irradiadas com e sem tríplice lavagem, sendo que as vazias foram irradiadas com dose absorvida de 26,0 kGy e as embalagens preenchidas com água destilada foram irradiadas com 17,0 kGy e 32,0 kGy no irradiador multipropósito de Co-60. Estas doses foram medidas com dosímetros do tipo PMMA, polimetil metacrilato.

\subsubsection{Ensaios com Embalagens Picadas}

\section{Embalagens Irradiadas Picadas em Frasco de Vidro}

Algumas embalagens foram cortadas em tiras $(1,1 \times 5,0) \mathrm{cm}$, (Fig. 7), contaminadas com 10 microlitros das duas formulações de clorpirifós e irradiadas com $22 \mathrm{ml}$ de água em frascos de vidro com as doses absorvidas de 15 kGy, 30 kGy, 50 kGy e 100 kGy na fonte de radiação gama do tipo "Gammacell".

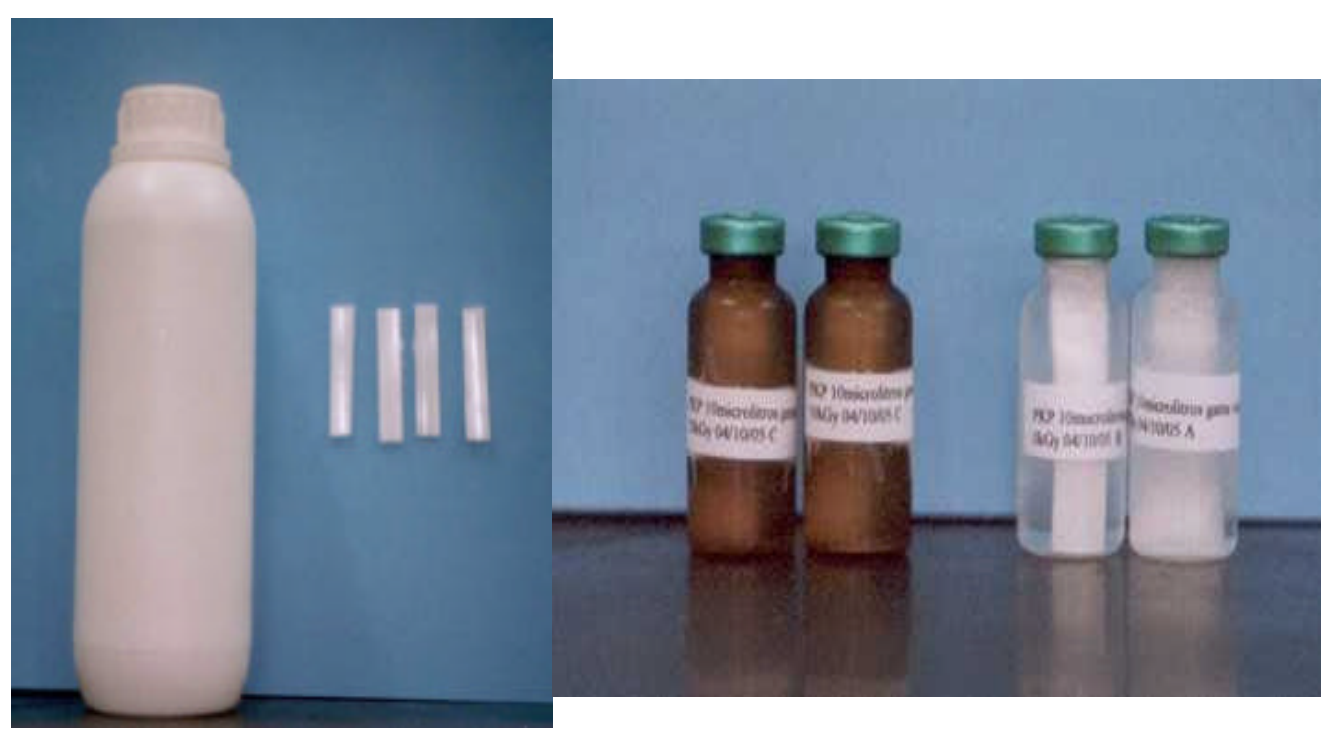

FIGURA 7. Embalagens do tipo COEX inteiras e cortadas para irradiação. 
Outro ensaio foi realizado com embalagens reais de agrotóxicos com as duas formulações comerciais. Estas embalagens foram picadas (simulando o triturador utilizado para reciclagem) e divididas em sacos com 20 gramas de pedaços cada um. Estas amostras foram irradiadas em triplicata em duas situações diferentes, metade com $50 \mathrm{~mL}$ de água destilada e a outra metade com $50 \mathrm{~mL}$ de água destilada e $25 \mathrm{~mL}$ de acetonitrila. Todas as amostras foram irradiadas com doses absorvidas de 25 kGy, 50 kGy, 100 kGy, 150 kGy e 200 kGy, na fonte de radiação gama tipo "Gammacell".

Para análise química quantitativa do clorpirifós, a solução aquosa foi separada das embalagens e o clorpirifós foi extraído com $25 \mathrm{ml}$ de acetonitrila em ultrassom por 15 minutos (Fig. 8). A solução aquosa foi diluída em acetonitrila na proporção de 1/1 e também foi submetida ao processo analítico.

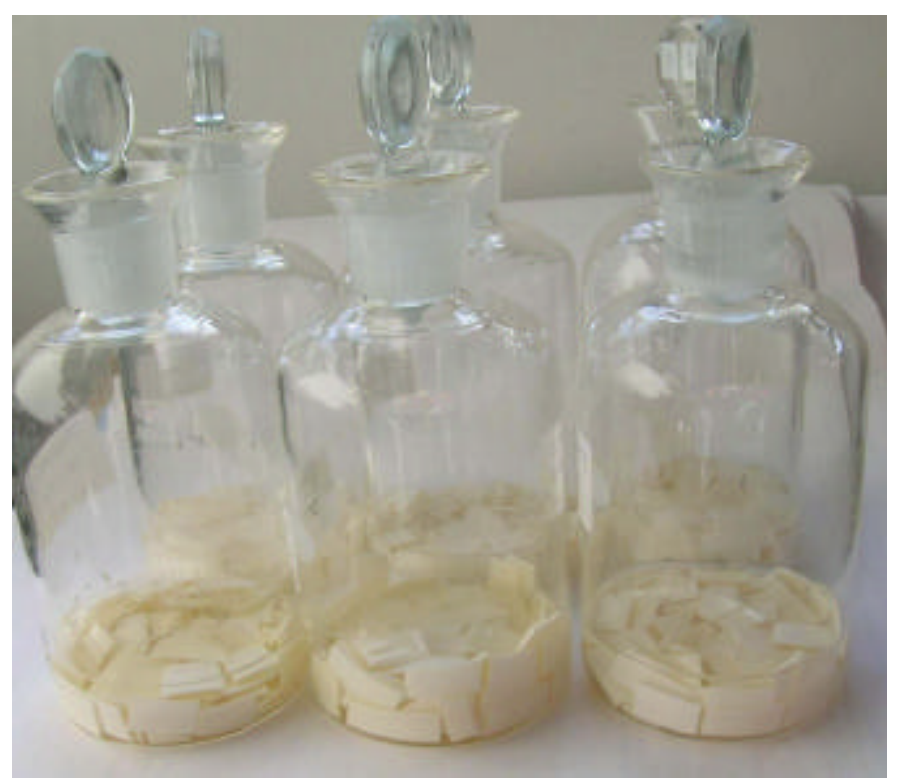

FIGURA 8. Embalagens do tipo COEX picadas após a irradiação e preparadas para extração do clorpirifós em acetonitrila. 


\subsection{RESULTADOS E DISCUSSÃO}

Os resultados são apresentados em duas etapas que são os ensaios com o clorpirifós em soluções preparadas em laboratório e os ensaios realizados com as embalagens contaminadas.

\subsection{Ensaios com o Clorpirifós em Solução}

A curva de calibração obtida nas condições descritas no item 2.1 Técnicas Analíticas, para o clorpirifós, é mostrada na Figura 9. As medidas foram feitas em triplicata $e$ os resultados apresentaram boa linearidade, reprodutibilidade de cerca de $5 \%$ (média de 10 análises) e limite mínimo de detecção de $0,3 \mu \mathrm{mol} . \mathrm{L}^{-1}$. Estes resultados demonstram que a metodologia analítica adotada e o ajuste da rampa de subida da temperatura da coluna do cromatógrafo são adequados para análise de clorpirifós em acetonitrila.

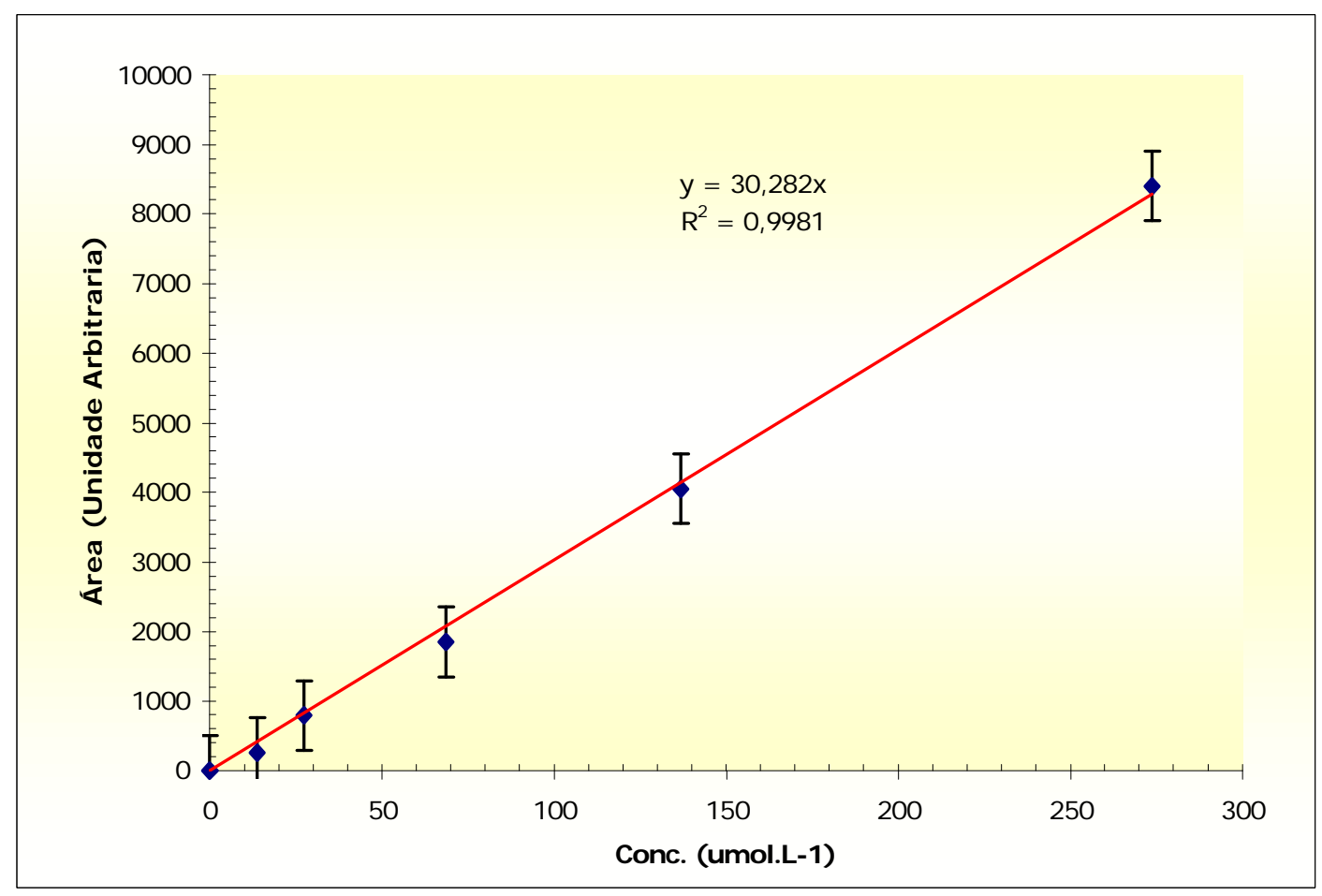

FIGURA 9. Curva de calibração do clorpirifós obtida no cromatógrafo a gás GC 17A-Shimadzu 
O clorpirifós comercial apresentou concentração elevada de outros produtos tóxicos que são utilizados como solventes e estabilizantes. Estes compostos orgânicos, identificados por espectrometria de massa, são mostrados nos cromatogramas da Figura 10.

No caso da formulação comercial "A" os principais compostos encontrados foram metilbenzeno, trimetilbenzeno, 2-propenilbenzeno (Indano) e naftaleno e no caso da formulação "B" foram encontrados, em maiores concentrações, os compostos hexilenoglicol, azuleno, 1,2-dimetillindano, naftaleno, 1-metilnaftaleno, 1,2-dimetilnaftaleno.

Esses compostos orgânicos utilizados na formulação comercial são tão ou mais tóxicos do que o próprio agrotóxico e, portanto, a sua degradação também é muito importante na redução da toxicidade total e a principal vantagem do uso da radiação ionizante é a não especificidade, que proporciona a degradação simultânea de todos os compostos orgânicos presentes.

Após a irradiação das soluções de clorpirifós em acetonitrila na fonte tipo Gamacell, em concentrações e doses absorvidas diferentes, os resultados mostraram que ocorreu a degradação do clorpirifós e, como era esperado, a eficiência variou de acordo com a dose e a concentração inicial (Figura 10).

Considerando-se que as concentrações de clorpirifós nestas amostras eram relativamente baixas, a eficiência de degradação não foi satisfatória, pois somente ocorreu a remoção total para a menor concentração de $13,7 \mu \mathrm{mol} . \mathrm{L}^{-1}$, com uma dose absorvida de $10 \mathrm{kGy}$. No caso das concentrações mais elevadas, a remoção variou de $40 \%$ a $80 \%$, para uma dose absorvida de $50 \mathrm{kGy}$, que é considerada elevada quando comparada com resultados obtidos por outros autores em estudos semelhantes com outros compostos orgânicos (Fig. 11) ${ }^{(38,67)}$. 

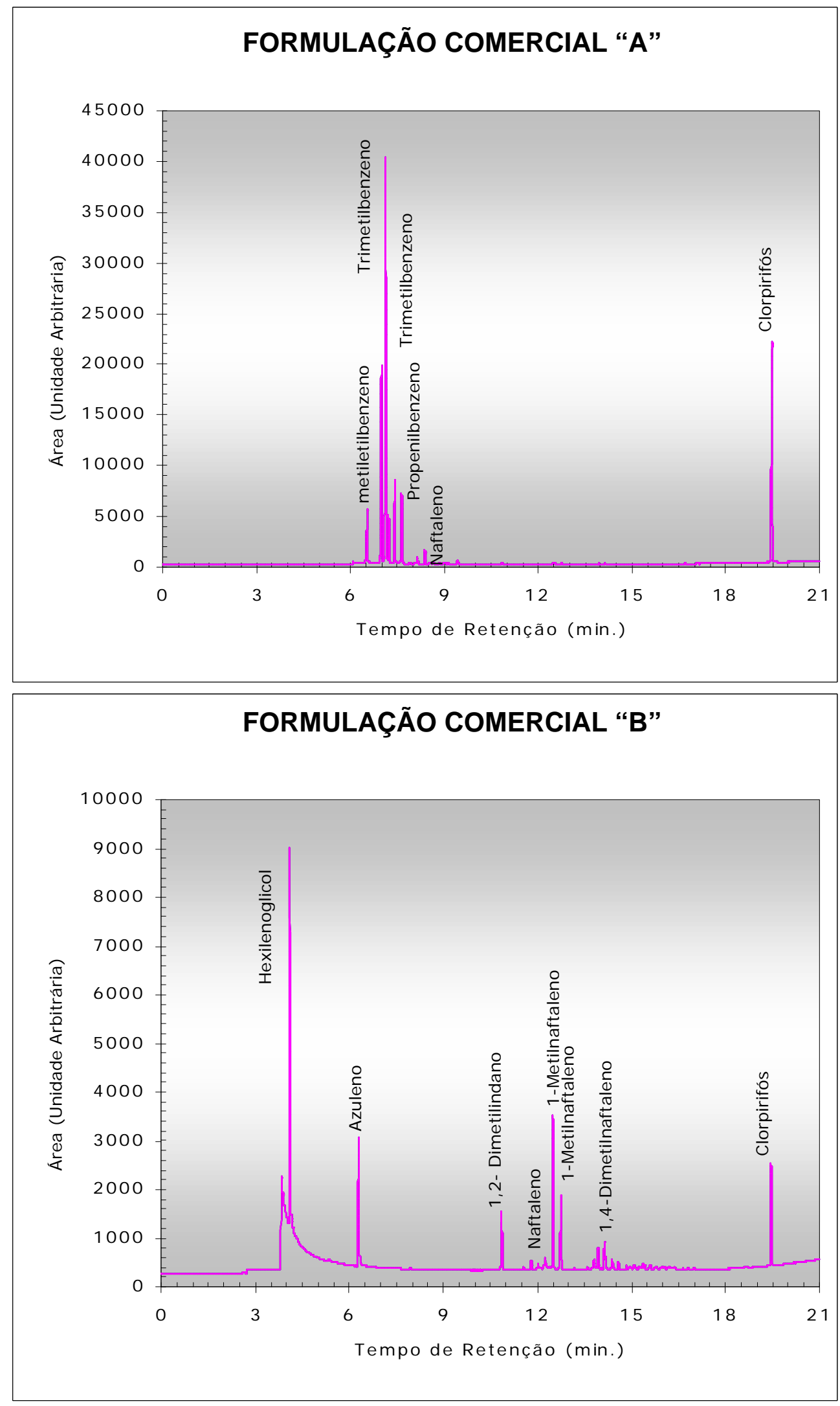

FIGURA 10. Cromatograma do clorpirifós comercial "A" e "B" com os outros produtos tóxicos presentes. 


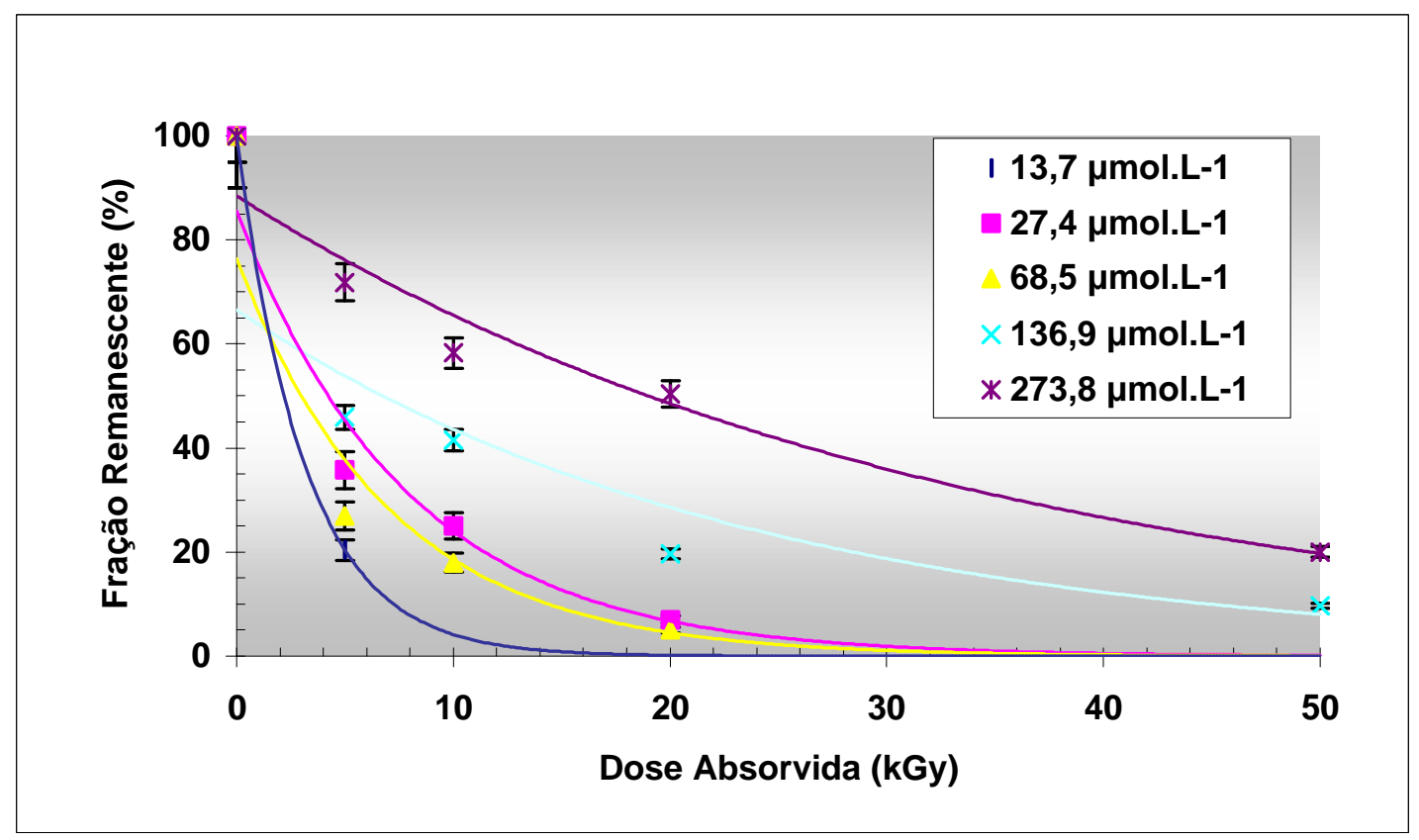

FIGURA 11. Degradação de clorpirifós em concentrações diferentes pela dose absorvida após irradiação gama

\subsubsection{Análise dos Subprodutos da Irradiação}

Após a irradiação, avaliaram-se os subprodutos formados por análise de cromatografia a gás associada à espectrometria de massa. Nas concentrações maiores que $27,4 \mu \mathrm{mol} . \mathrm{L}^{-1}$, foram detectados os compostos resultantes da oxidação e hidrólise do clorpirifós, que são o clorpirifós-oxon e o 3,5,6-tricloro 2 piridinol (3,5,6 TCP). Este processo de oxidação e hidrólise está esquematizado na Figura 12.

Pesquisas na literatura revelaram que estes produtos são resultantes da degradação natural do clorpirifós no meio ambiente e também da biotransformação em animais contaminados. Estes subprodutos foram detectados por outros autores que estudaram os produtos do metabolismo de clorpirifós em animais $^{(68)}$, pois foram detectados em sua urina, em plantas $^{68}$, e na degradação no solo e na água ${ }^{70}$. Este processo de oxidação e hidrólise está esquematizado na Figura 12. 
Esta constatação foi muito importante no desenvolvimento do trabalho, pois demonstrou que a decomposição do clorpirifós segue o mesmo mecanismo de oxidação e hidrólise, quer seja por degradação ambiental e biológica ou pelo processamento por radiação ionizante. Este fato dá a segurança da não formação de compostos desconhecidos ou que venham a por em risco todo o sistema, quando este processo é utilizado.

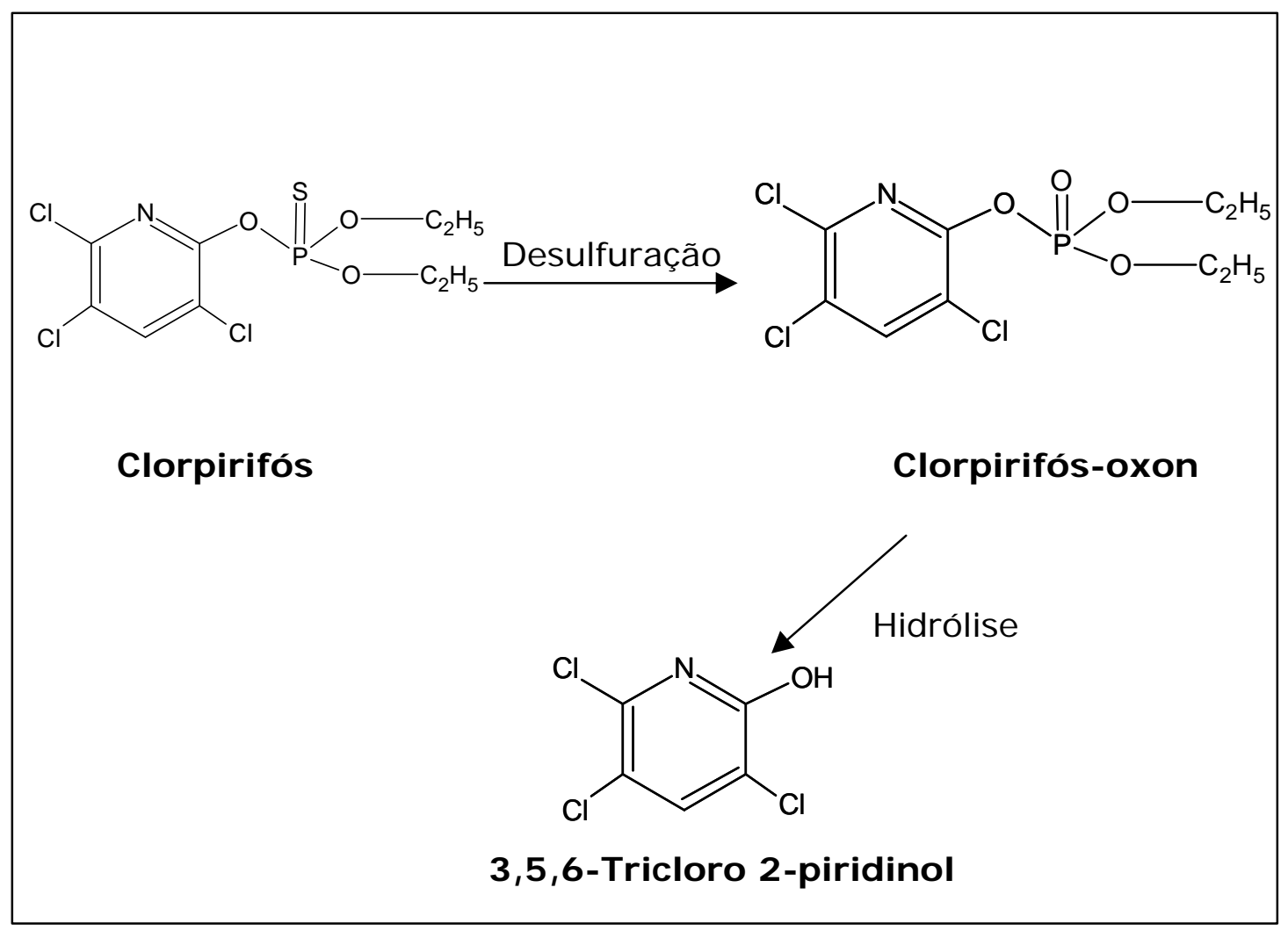

FIGURA 12. Mecanismo do processo de decomposição do clorpirifós e formação dos produtos de oxidação e hidrólise após irradiação gama.

As análises quantitativas dos compostos clorpirifós-oxon e o 3,5,6tricloro-2- piridinol (3,5,6 TCP) nas amostras irradiadas com doses crescentes, demonstraram que houve um aumento nas concentrações à medida que o clorpirifós era degradado (Figuras 13 e 14). No caso das soluções de clorpirifós com $13,7 \mu \mathrm{mol} . \mathrm{L}^{-1}$ e $27,4 \mu \mathrm{mol} . \mathrm{L}^{-1}$, os subprodutos não foram detectados, o que indica que a menor dose absorvida aplicada foi suficiente para a decomposição total destes compostos. 

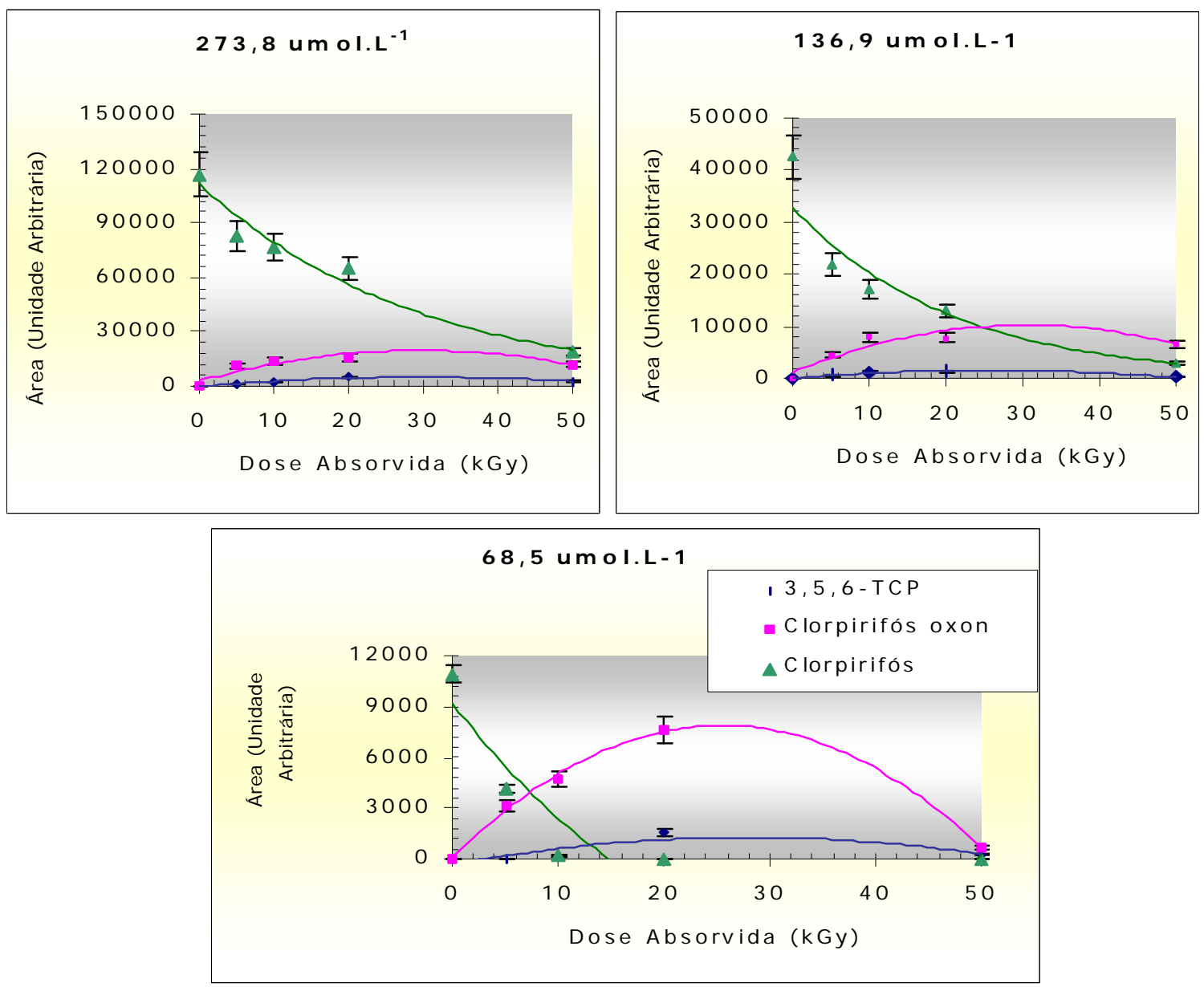

FIGURA 13. Degradação do clorpirifós e formação dos subprodutos clorpirifósoxon e 3,5,6-tricloro-2-piridinol na radiólise de diferentes concentrações em função da dose absorvida.
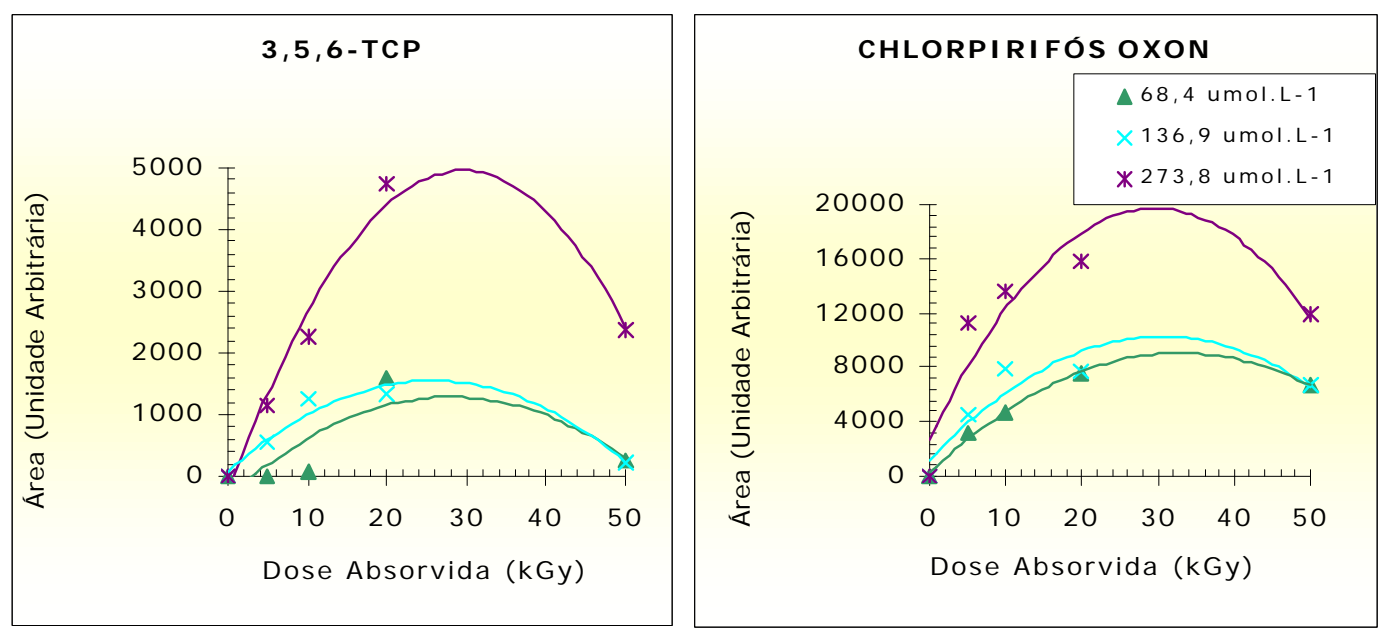

FIGURA 14. Formação dos subprodutos clorpirifós-oxon e 3,5,6-tricloro-2piridinol na radiólise gama de diferentes concentrações em função da dose absorvida. 


\subsubsection{Efeito da Adição de Água na degradação do Clorpirifós}

A presença de moléculas de água é importante na geração dos radicais livres que atuam na decomposição dos compostos orgânicos, mas no caso do clorpiridós é necessário a presença da acetonitrila como solvente, portanto a proporção ideal de água e acetonitrila que simultaneamente dissolva o clorpirifós e forneça os radicais livres necessários deve ser conhecida.

Em vista disso, realizou-se um ensaio com dois padrões de clorpirifós em acetonitrila nas concentrações de $800 \mu \mathrm{mol} . \mathrm{L}^{-1}$ e $1600 \mu \mathrm{mol} . \mathrm{L}^{-1}$, onde foi adicionada água em proporções crescentes de $1 / 9$ até $9 / 1$ de água em acetonitrila.

Os resultados obtidos confirmaram que, quanto maior a proporção de água, mais eficiente é o processo de degradação do clorpirifós pela radiação ionizante. Esta esta proporção deve ser maior que 50\%, com uma eficiência máxima em $70 \%$ de água, acima desta proporção o clorpirifós começa a precipitar, diminuindo a concentração inicial em solução (Fig. 15).

Para confirmar estas proporções os dados foram avaliados pelo cálculo do $G$ de destruição $(G d)$, que é definido como o número de moléculas destruídas em um sistema pela absorção de $100 \mathrm{eV}$ de energia, sendo dado por $^{71}$ :

\section{$G_{d}=\Delta R D N a / D\left(6,24 \times 10^{15}\right)$}

onde:

$\mathrm{G}_{\mathrm{d}}=\mathrm{G}$ de destruição $=\mathrm{mol} / \mathrm{J}$

$\Delta R D=$ diferença entre as concentrações inicial e final para uma determinada dose em $\mathrm{mol} / \mathrm{L}$

$D=$ dose em kGy

$6,24 \times 10^{15}=$ constante para converter kGy em $100 \mathrm{eV} / \mathrm{L}$

$\mathrm{Na}=$ número de avogadro $=6,023 \times 10^{23}$

$O$ valor de $G_{d}$ foi calculado para todas as amostras com diferentes proporções de água/acetonitrila e os resultados são mostrados na Figura 16. Estes dados confirmaram que os melhores resultados foram obtidos quando na 
mistura, a proporção de água variava de $50 \%$ a $70 \%$. Em misturas com proporção menor que $50 \%$ de água, a acetonitrila é a responsável pela diminuição da taxa de degradação e em misturas com proporção maior que $70 \%$, ocorre a precipitação do clorpirifós e o rendimento de degradação é menor.

O número de moléculas degradadas por absorção de unidade de energia é maior para doses menores, em virtude das reações entre os próprios radicais e entre os subprodutos formados, que ocorrem quando se utiliza doses muito elevadas.

A redução da eficiência da radiação ionizante na degradação de compostos orgânicos causada pela acetonitrila foi confirmada em estudos de DeMatteo et all $^{72}$. Usando técnicas diferentes eles demonstraram que 0 coeficiente de reação do radical hidroxila com naftaleno é cerca de 5,8 vezes menor em acetonitrila do que em água e no caso da reação do radical hidroxila com benzeno a reação em acetonitrila é cerca de 65 vezes menor. A reatividade absoluta do radical hidroxila com anéis aromáticos é reduzida em acetonitrila em relação à água, permitindo a detecção dos subprodutos clorpirif'ós-oxon e 3,5,6tricloro-2-piridinol (TCP).

Uma possível explicação, obtida na literatura, é que a exposição da água à radiação ionizante leva á formação de espécies primárias como o elétron solvatado (e-aq), o radical átomo de hidrogênio $\cdot \mathrm{H}$ e o radical hidroxila $\mathrm{OH}$, enquanto que a acetonitrila é um solvente polar com baixa reatividade ao radical hidroxila. Já a água atua como um doador de hidrogênio em virtude da carga mais positiva de seu hidrogênio. Como tal, a água estabiliza melhor o estado de transição e este estado é formado mais rapidamente no caminho da absorção da radiação. Esta mudança no estado de transição pode ser observado com base no comprimento da banda de ligação C-O formada, que é maior em acetonitrila $(2,06$ A) que o valor padrão para reação de adição da fase gasosa (2,02 A) e maior ainda em água $(2,08 \mathrm{~A})^{73}$. 

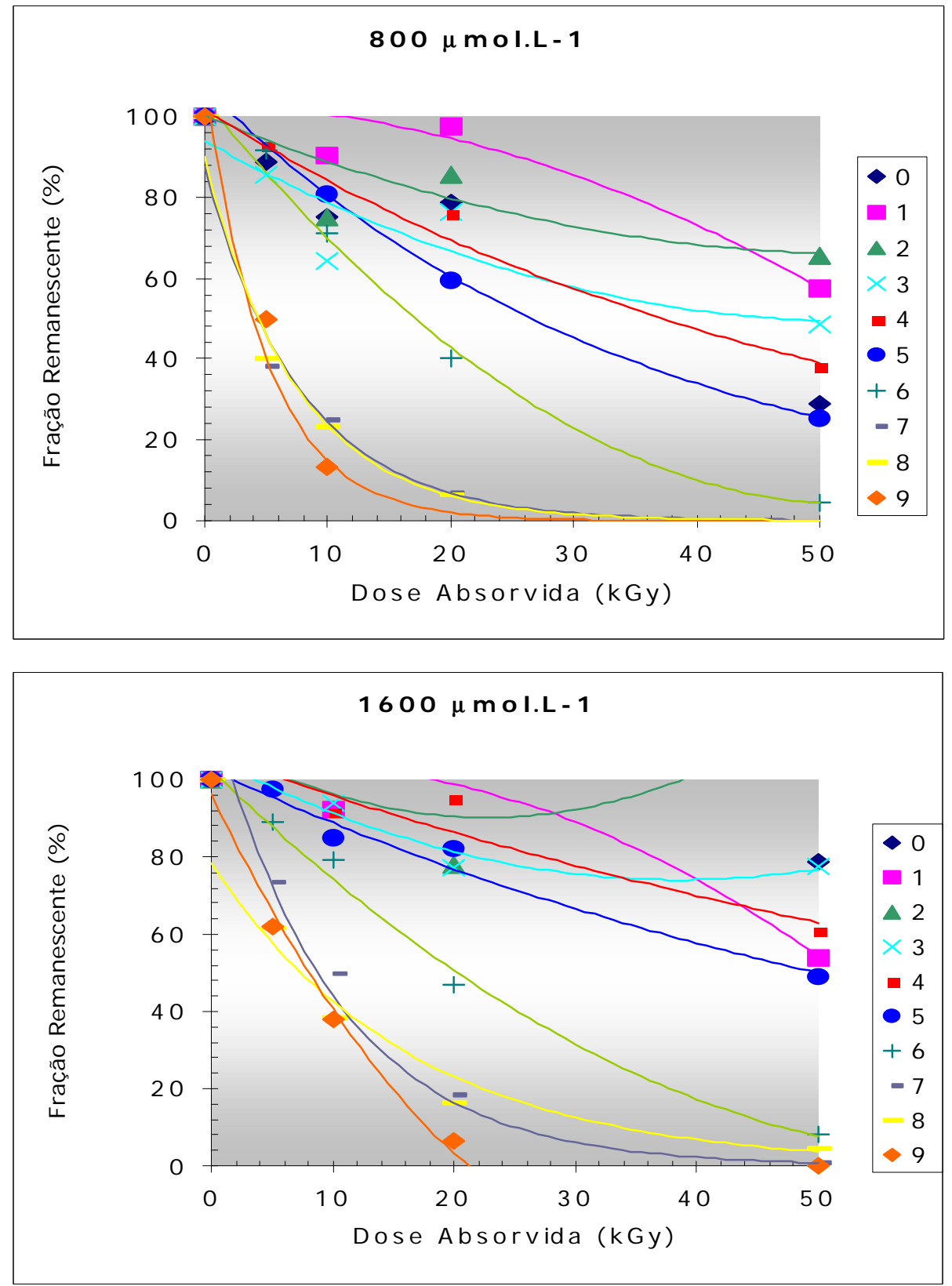

FIGURA 15. Degradação do clorpirifós em duas concentrações diferentes e nas várias proporções água/acetonitrila pela dose absorvida, após irradiação gama.

Onde:

- 0 -zero de água +10 de acetonitrila

- 1 - uma de água +9 de acetonitrila

- 2 - duas de água +8 de acetonitrila

- 3 -três de água +7 de acetonitrila

- 4-quatro de água + 6 de acetonitrila

- 5 - cinco de água + 5 de acetonitrila

- 6 - seis de água +4 de acetonitrila

- 7 - sete de água + 3 de acetonitrila

- 8 - oito de água +2 de acetonitrila

- 9 -nove de água + 1 de acetonitrila 

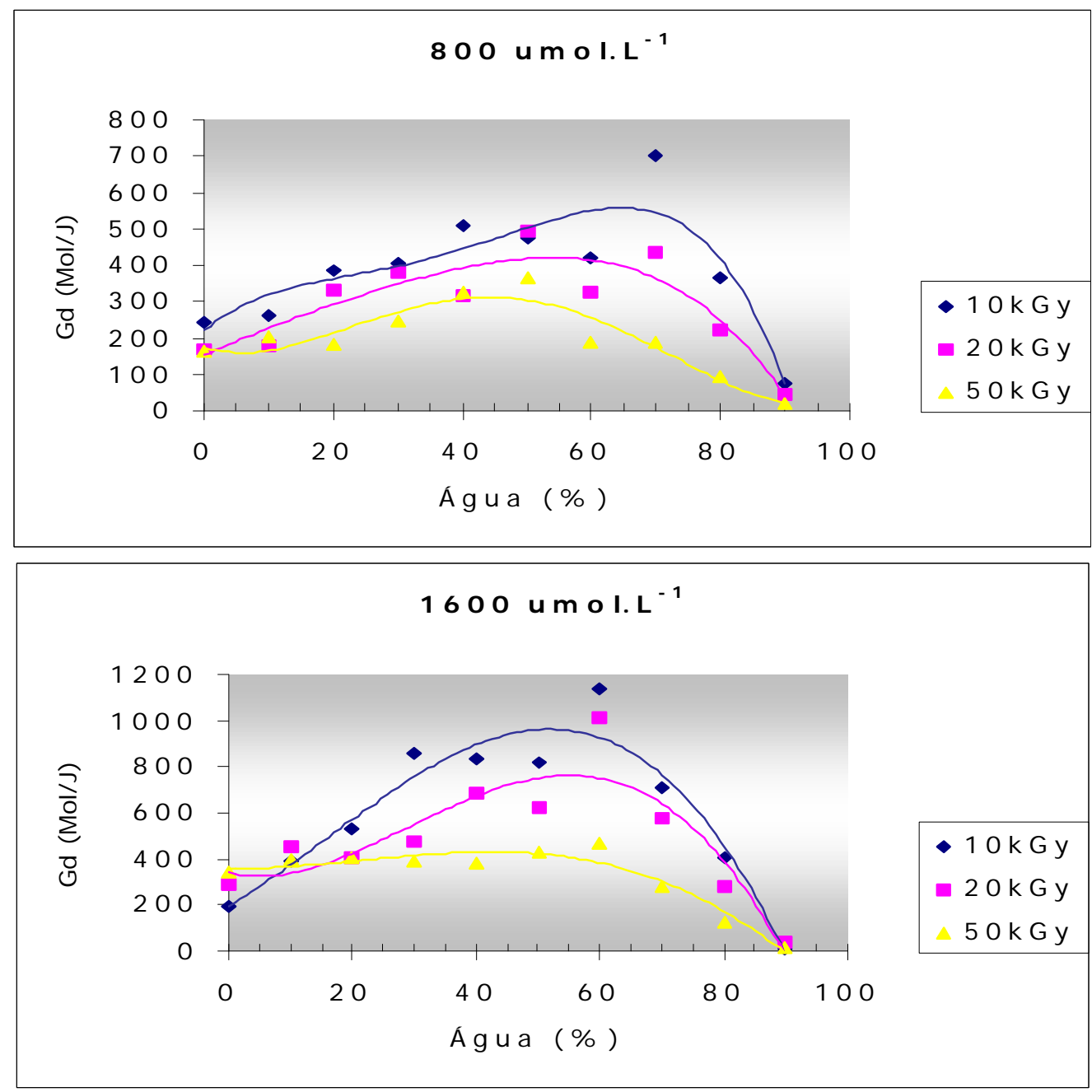

FIGURA 16. Rendimento $\left(G_{d}\right)$ da degradação do clorpirifós em duas concentrações diferentes e nas várias proporções de água/acetonitrila em função da dose absorvida. 


\subsection{Degradação do Clorpirifós Presente nas Embalagens}

Os primeiros testes de degradação de clorpirifós presente nas embalagens com radiação ionizante, foram realizados com embalagens inteiras e posteriormente realizou-se ensaios com embalagens trituradas.

\subsubsection{Embalagens Irradiadas Inteiras}

Uma etapa importante é o estudo dos critérios de avaliação sobre a presença ou não da contaminação na embalagem. Para estabelecer estes critérios foram realizados alguns testes onde a tríplice lavagem foi realizada de acordo com normas pré-estabelecidas, ou seja lavagem da embalagem com $1 / 4$ do seu volume, por três vezes.

Após a tríplice lavagem procedeu-se a extração de possíveis resíduos de clorpirifós, utilizando-se a acetonitrila como solvente. Verificou-se que a embalagem permanece contaminada, mesmo após a tríplice lavagem e, dependendo do tempo de contacto com a acetonitrila, a concentração de clorpirifós aumenta (Tabela 8). Destes resultados concluiu-se que, mesmo as embalagens tipo COEX não possuem impermeabilidade total ao agrotóxico, embora estejam dentro dos limites permitidos pela legislação.

Para o presente estudo estabeleceu-se que as avaliações seriam realizadas com um tempo de extração da acetonitrila de 30 minutos e de 24 horas.

TABELA 8. Concentrações de clorpirifós após tríplice lavagem extraído com acetonitrila.

\begin{tabular}{c|cc}
\hline NÚMERO DE EXTRAÇÕES & TEMPO DE EXTRAÇÃO & $\begin{array}{c}\text { CONCENTRAÇÃO } \\
\text { DE CLORPIRIFÓS } \\
\left(\mu \mathrm{mol.L}{ }^{-1}\right)\end{array}$ \\
\hline PRIMEIRA & 10 minutos & 484,9 \\
SEGUNDA & 10 minutos & 29,4 \\
TERCEIRA & 30 minutos & 53,9 \\
QUARTA & 24 horas & 85,6 \\
\hline
\end{tabular}


$\mathrm{Na}$ Tabela 9 são apresentados os resultados obtidos com as embalagens de clorpirifós após irradiação em diferentes condições e doses absorvidas (E1 a E7) acompanhados dos respectivos controles não irradiados (EOA a EOD).

O clorpirifós foi extraído da embalagem com acetonitrila por 30 minutos e por 24 horas. Em todas as situações houve diminuição da concentração de clorpirifós após a irradiação, mas a tríplice lavagem antes da irradiação foi fundamental para a redução da contaminação. Somente a tríplice lavagem reduziu a contaminação de 140.352,0 $\mu \mathrm{mol}^{-L^{-1}}$ (EOA) para 484,9 $\mu \mathrm{mol}^{-L^{-1}}$ (EOC).

Comparando-se as embalagens E4 e E5 com E6 e E7, todas com tríplice lavagem, notou-se um aumento na eficiência de degradação de clorpirifós nas embalagens E6 e E7 onde havia um volume maior de água destilada. A presença de água mostrou-se mais eficiente na degradação de clorpirifós que o aumento da dose absorvida. Neste experimento preliminar a situação onde houve remoção total do clorpirifós foi a da embalagem E7, com tríplice lavagem, presença de água destilada e dose absorvida de 32 kGy.

TABELA 9. Concentrações de clorpirifós nas embalagens após processamento no Irradiador Multipropósito de Co-60 e extração com acetonitrila por 30 minutos e 24 horas.

\begin{tabular}{|c|c|c|c|c|c|}
\hline \multirow[b]{2}{*}{ EMBALAGEM } & \multirow{2}{*}{$\begin{array}{l}\text { DOSE } \\
\text { ABSORVIDA } \\
\text { (kGy) }\end{array}$} & \multirow{2}{*}{$\begin{array}{l}\text { TRÍPLICE } \\
\text { LAVAGEM }\end{array}$} & \multirow[b]{2}{*}{ PREENCHIMENTO } & \multicolumn{2}{|c|}{$\begin{array}{c}\text { CLORPIRIFÓS } \\
\left(\mu \mathrm{mol} . \mathrm{L}^{-1}\right)\end{array}$} \\
\hline & & & & $\begin{array}{c}1 \mathrm{a} \\
\text { extração } \\
30 \mathrm{~min}\end{array}$ & $\begin{array}{c}2 a \\
\text { extração } \\
24 \mathrm{~h}\end{array}$ \\
\hline E0A* & 00 & não & Vazia & $140.352,0$ & $6.591,0$ \\
\hline E1 & 26 & não & Vazia & $80.992,0$ & $2.290,2$ \\
\hline${\mathrm{E} 0 \mathrm{~B}^{*}}^{*}$ & 00 & não & Água destilada & $35.484,0$ & $3.435,5$ \\
\hline E2 & 17 & não & Água destilada & $21.448,9$ & $2.843,0$ \\
\hline E3 & 32 & não & Água destilada & $20.704,0$ & $2.021,7$ \\
\hline EOC* & 00 & sim & Vazia & 484,9 & 85,6 \\
\hline E4 & 26 & sim & Vazia & 137,2 & 21,1 \\
\hline E5 & 26 & $\operatorname{sim}$ & Vazia & 153,2 & 101,0 \\
\hline EOD* & 00 & $\operatorname{sim}$ & Água destilada & 70,0 & 45,6 \\
\hline E6 & 17 & sim & Água destilada & 7,8 & $<$ LMD \\
\hline E7 & 32 & $\operatorname{sim}$ & Água destilada & $<$ LMD & $<$ LMD \\
\hline
\end{tabular}




\subsubsection{Embalagens Irradiadas Picadas}

Quando se propõe uma tecnologia para uso em escala comercial, alguns fatores como a aplicabilidade e a praticidade devem ser considerados. $\mathrm{O}$ sistema de irradiação com o preenchimento das embalagens com água, embora tenha se mostrado mais eficiente, não é praticamente viável, pelo disperdício tanto da água como da dose absorvida de radiação, assim estudou-se outra forma de irradiação, mais econômica e prática. A idéia inicial era irradiar a embalagem no seu formato original, contudo pode ser necessário o corte ou a moagem desta, para um melhor aproveitamento do sitema de irradiação, principalmente no caso da utilização do acelerador de elétrons.

Os resultados dos ensaios com pedaços pequenos contaminados com as formulações comerciais "A" e "B" e irradiados em frascos de vidro com água e lacrados serão tratados separadamente dos ensaios que simularam uma situação mais próxima à realidade que foram os sacos de plástico com cerca de $30 \mathrm{~g}$ de embalagens em cada um.

\section{Embalagens Irradiadas Picadas em Frasco de Vidro}

As embalagens irradiadas em frascos de vidro com formulações comerciais "A" e "B" apresentaram variações na eficiência de degradação de clorpirifós. No caso da formulação $B$, que é uma emulsão concentrada com viscosidade de $364 \mathrm{cP}$, o agrotóxico foi removido menos que $40 \%$ com $15 \mathrm{kGy}$, enquanto que na formulação "A", que é um concentrado emulsionável com viscosidade de $10 \mathrm{cP}$, o clorpirifós apresentou uma remoção $>80 \%$ para a mesma dose absorvida (Figura 17).

A viscosidade e a solubilidade nos solventes pode ser a responsável pelos resultados, pois interferem nas reações do agrotóxico com radical hidroxila. Outro fator que pode ser responsável pelo menor rendimento na degradação do clorpirifós é sua possivel aderência a parede da embalagem, dificultando um ataque efetivo dos radicais formados pela radiólise da água.

A degradação dos solventes também variou com a formulação, no caso do produto B, para uma dose absorvida de 20 kGy, observou-se uma taxa de 
degradação de 65 a $75 \%$ dos solventes usados para solubilizar o clorpirifós. Os solventes que necessitaram de doses maiores para degradação foram os derivados do naftaleno que são metilnaftaleno e dimetilnaftaleno, que também estavam presentes em concentrações maiores na formulação comercial. Com uma dose de $50 \mathrm{kGy}$ praticamente não foram detectados solventes enquanto a fração remanescente de clorpirifós foi $20 \%$ (Fig. 17).

Os solventes, apesar de pouco solúveis em água, são de 20 a 60 vezes mais solúveis do que o clorpirifós. No caso da formulação comercial $\mathrm{B}$, os compostos metiletilbenzeno e trimetilbenzeno foram removidos com eficiência maior do que o clorpirifós, mas foram necessárias doses absorvidas maiores para remoção total dos solventes

\section{Embalagens Irradiadas Picadas em Sacos de Polietileno}

Os resultados dos ensaios com embalagens reais picadas contaminadas com as duas formulações de agrotóxicos, sem tríplice lavagem, demonstraram um outro fator a ser levado em consideração quando a contaminação é muito elevada, que é a solubilidade em água do agrotóxico. No caso do clorpirifós em concentrações muito elevadas, uma parte do agrotóxico precipitou dificultando a interação com os radicais livres.

Dessa forma fez-se um segundo experimento, exatamente igual ao primeiro, mas adicionando-se $25 \mathrm{~mL}$ de acetonitrila que foi suficiente para dissolver o clorpirifós remanescente. Após a irradiação as embalagens foram separadas da solução e o clorpirifós extraído com acetonitrila pura e analisado. A análise de clorpirifós foi realizada tanto na embalagem, como na solução. Os resultados destes dois experimentos são mostrados na Figura 17, onde pode-se observar o comportamento da formulação comercial "A" e "B", quando irradiadas em solução aquosa e em solução com água mais $25 \%$ de acetonitrila.

A presença de acetonitrilia aumentou significativamente a concentração de clorpirifós que foi exposta à radiação e, consequentemente, a eficiência do processamento, como pode ser observado pela variação da concentração inicial de clorpirifós apresentada pela duas formulações em solução aquosa e em água mais acetonitrila. 
Outro resultado importante obtido foi a baixa concentração e, algumas vezes, ausência de clorpirifós na solução retirada das embalagens após a irradiação, o que dá a segurança que o clorpirifós foi realmente removido e não solubilizado (Fig. 18).
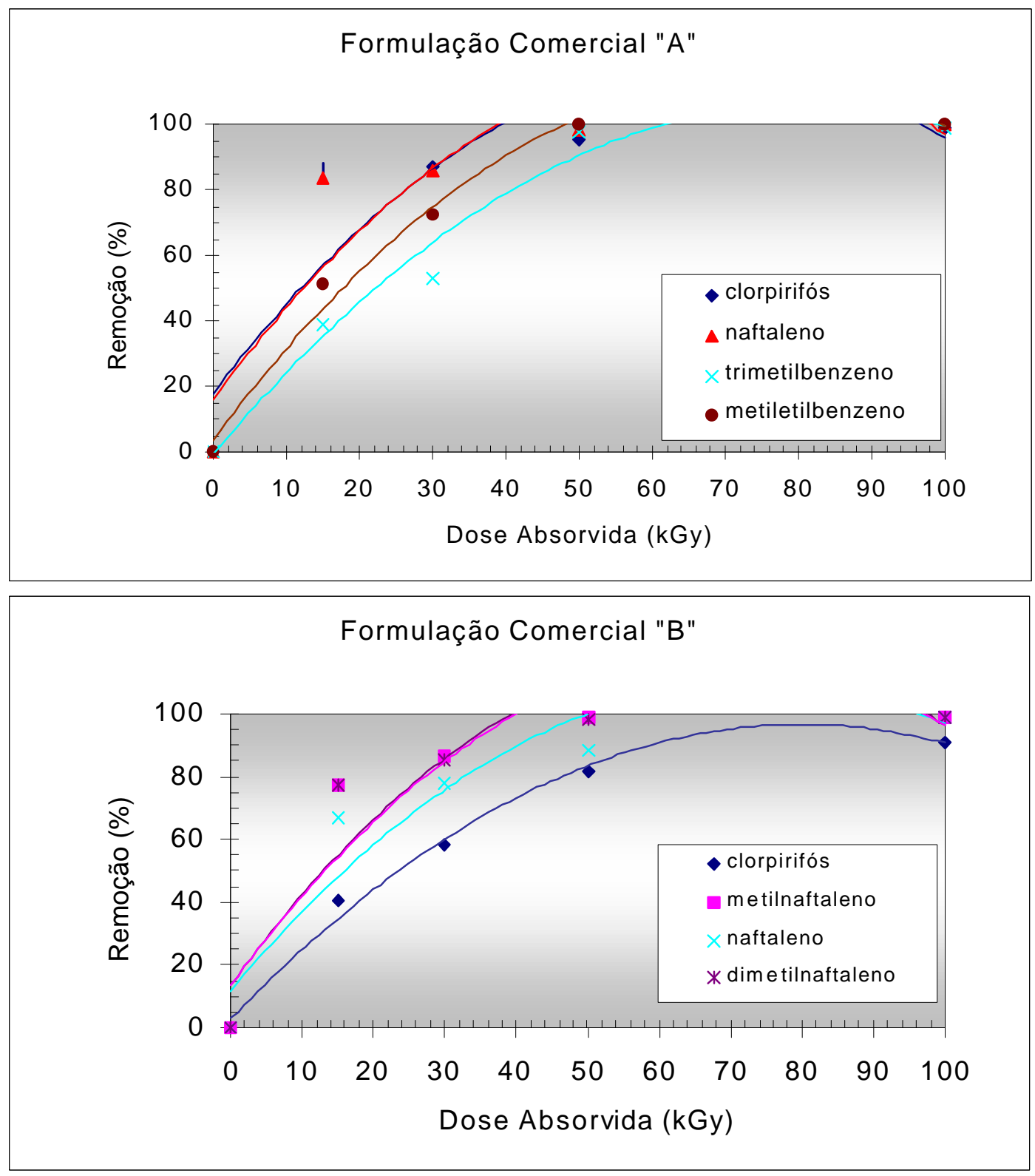

FIGURA 17. Degradação dos compostos orgânicos presentes nas duas duas formulações comerciais de clorpirifós, após irradiação das embalagens em diferentes doses absorvidas. 

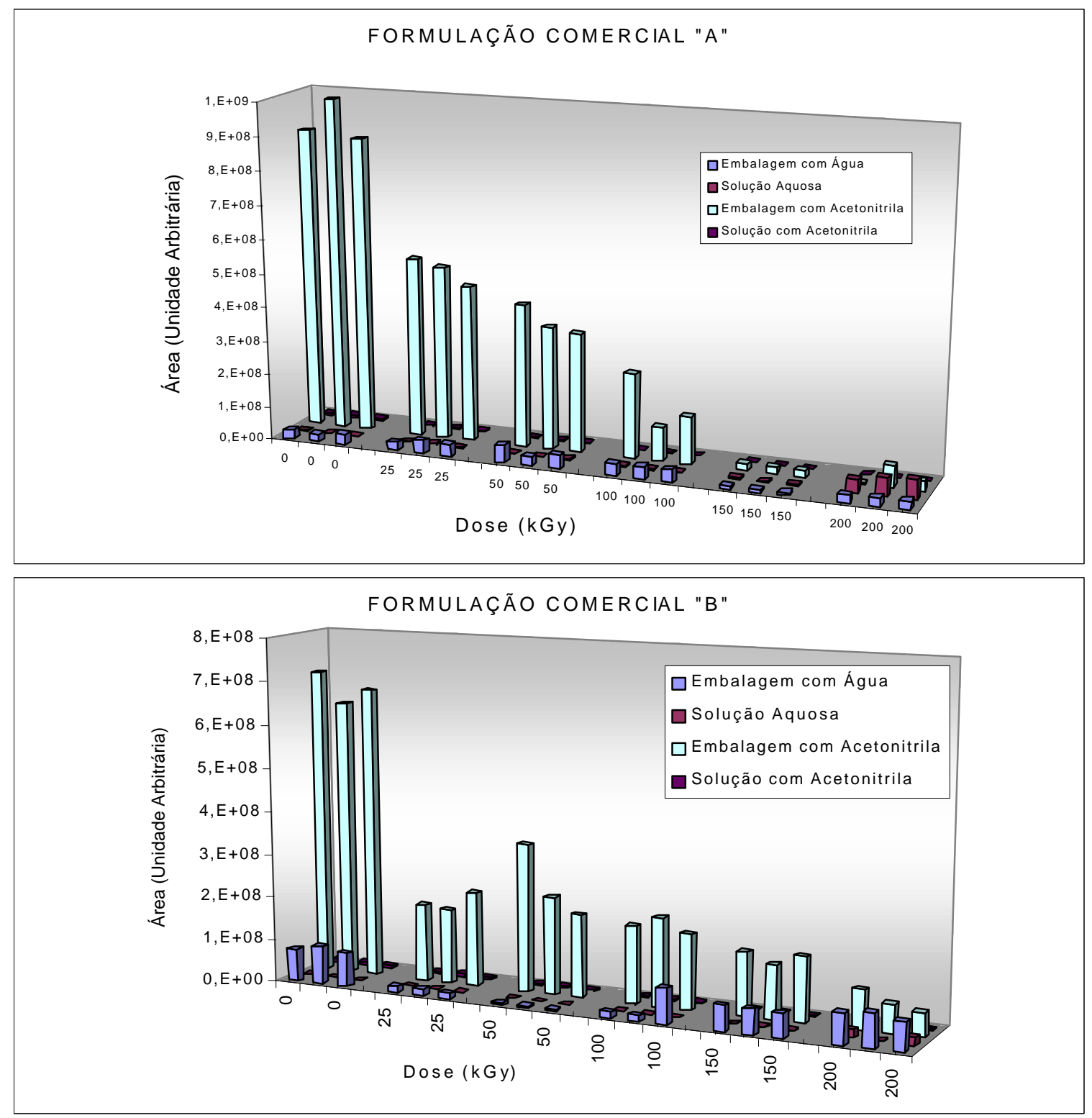

FIGURA 18. Degradação do clorpirifós em embalagens reais picadas das duas formulações comerciais, após irradiação em diferentes doses absorvidas. 


\subsection{CONCLUSÕES}

Os estudos e experiências realizadas demonstraram que:

- A degradação radiolítica do clorpirifós forma os mesmos produtos encontrados nos processos biológicos de degradação do inseticida.

- O clorpirifós-oxon e o 3,5,6-tricloro-2-piridinol, produtos de degradação radiolítica do clorpirifós, também sofrem degradação quando expostos à radiação ionizante.

- A taxa de degradação do clorpirifós é aumentada quando irradiado com uma solução formada pela mistura de água mais acetonitrila do que em acetonitrila.

- A viscosidade do clorpirifós influencia no rendimento da degradação, pois, quanto maior a viscosidade maior é a aderência do inseticida nas paredes da embalagem dificultando $\mathrm{o}$ ataque dos radicais formados pela radiólise da água.

- A descontaminação é mais eficiente nas embalagens irradiadas picada do que nas embalagens irradiadas inteira.

- A descontaminação das embalagens é mais eficiente quando irradiadas com uma solução de água mais acetonitrila do que irradiadas somente com água.

- Os solventes usados nas formulações A e B também são degradados pela radiação, porém, o solvente da formulação $B$ que é um derivado do naftaleno é mais resistente a degradação do que o solvente da formulação A que é um derivado do benzeno. 


\section{REFERÊNCIAS}

1. DERÍSIO, J. C. Introdução ao controle de poluição ambiental. Signus Editora, São Paulo, 2000. cap. 2, usos da água. p. 15-84.

2. QUEIROZ, M. A. Gerenciamento de resíduos industriais: um desafio constante. Banas Qualidade. N.158, p. 108-111, 2005.

3. BRASIL. DECRETO $n^{\circ} 4.074$, de 4 de janeiro de 2002. Diário Oficial [da] República Federativa do Brasil, Poder Executivo, Brasília, DF, 8 jan. 2002, Seção 1.

4. MÍDIO, A. F.; DA SILVA, E. S. Insecitidas-acaricidas organofosforados e carbamatos. Editora Roca Ltda, São Paulo, 1995. cap. 1, introdução. p. 1-10 .

5. ANDEF - Associação Nacional de Defesa Vegetal. Manual do uso correto e seguro de produtos fitossanitários/agrotóxicos. Disponível em: $<$ http://www.andef.com.br. Acesso em jan. 2006.

6. SINDAG - Sindicato Nacional da Indústria de Produtos para Defesa Agrícola. Biblioteca-dados. Disponível em: <http://www.sindag.com.br. Acesso em jan. 2006.

7. SINDAG - Sindicato Nacional da Indústria de Produtos para Defesa Agrícola. Defensivos agrícolas em linha de comercialização por ingredientes ativos.

Disponível em:<http://www.sindag.com.br/new/upload/inforsetor/ingredientes_ativos.xls. Acesso em dez. 2005.

8. SINDAG. Sindicato Nacional da Indústria de Produtos para Defesa Agrícola. Defensivos agrícolas em linha de comercialização - junho de 2005. Disponível em: <http://www.sindag.com.br/upload/inforsetor/PL.Junho-05.xls. Acesso em set. 2005.

9. ABNT - ASSOCIACÃO BRASILEIRA DE NORMAS TÉCNICAS, NBR 12697: produto técnico e formulações de agrotóxicos - terminologia. Rio de Janeiro, 1997b.

10. PRATA, F. Comportamento do glifosato no solo e deslocamento miscível de atrazina. Tese apresentada na Escola Superior de Agricultura "Luiz de Queiroz", Universidade de São Paulo, para obtenção do título de Doutor em Agronomia, Área de Concentração: Solos e Nutrição de Plantas. Piracicaba SP -Br. Junho de 2002.

11. BRASIL. PORTARIA $n^{0} 03$, de 16 de janeiro de 1992. Diário Oficial [da] República Federativa do Brasil, Poder Executivo, Brasília, DF, 04 fev. 1992. Seção 1. 
12. DOW AGROSCIENCE. Toxological properties of chlorpyrifos. Disponível em:

<http://www.dowagro.com/webapps/lit/litorder.asp?filepath=chlorp/pdfs/noreg/0 10-90067.pdf\&pdf=true. Acesso em jun. 2002.

13.DOW AGROSCIENCE. Physical/chemical properties. Disponível em: <http://www.dowagro.com/chlorp/science/pro.htm. Acesso em fev. 2005.

14.DOW AGROSCIENCE. Lorsban $480 \mathrm{Br}$. Disponível em: <http://www.dowagro.com/webapps/lit/litorder.asp?filepath=br/pdfs/noreg/01300027.pdf\&pdf=true. Acesso em fev. 2005.

15. SINDAG - Sindicato Nacional da Indústria de Produtos para Defesa Agrícola. Defensivos agrícolas em linha de comercialização-junho de 2005. Disponível em: <htt://www.sindag.com.br/upload/inforsetor/PL.junho-05.xls. Acesso em set. 2005.

16. PADOVANI, L.; CAPRI, E. Chlorpyrifos-methyl dissipation in a small adjacent water body following applications to citrus. Chemosphere. 58(9): 1219-1229, 2005.

17.LAABS, V.; AMELUNG, W.; PINTO, A.; ALTSTAEDT,A.; ZECH, W. Leaching and degradation of corn an soybean pesticides in a oxisol of the brasilian cerrados. Chemosphere. 41(9): 1441-1449, 2000.

18. MATSUMURA, F. Toxological of insecticides. Plenum Press, NY, 1985. cap. 8, movement of insecticides in the environment. p. 383-402.

19. FELSOT, A.; DAHM, P. A. Sorption of organophosphorous and carbamate insecticides by soil. J. Agr. Food Chem., 27(3): 557-563, 1979.

20.RACKE, K. D.; STEELE, K. P.; YODER, R. N.; DICK, W. A.; AVIDOV, E. Factors affecting the hydrolitic degradation of chlorpyrifos in soil. J. Agr. Food Chem., 44(6): 1582-1592, 1996.

21. NOBLET, J. A.; SMITH, L. A.; SUFFET, I. Influence of natural dissolved organic matter, temperature and mixing on the abiotic hydrolysis of triazine organophosphate pesticides. J. Agr. Food Chem., 44(13): 3685-3693, 1996.

22. GETZIN, L. W. Dissipation of chlorpyrifos from dry surfaces. Journal of Ecomonic Entomology. 74(6): 707-713, 1981.

23. MARINO, D.; RONCO, A. Cypermethrin and chlorpyrifos concentration levels in surface water bodies of the pampa ondulata, Argentina. Bull. Environ. Contam. Toxicol., 75(4): 820-826, 2005.

24.JERGENTZ, S.; MUGNI, H.; BONETTO, C.; SCHULZ, R. Assesment of insecticide contamination in runoff and stream water of small agricultural 
streams in the main soybean area of Argentina. Chemosphere. 61(6):817-826, 2005.

25.INPEV - Instituto Nacional de Processamento de Embalagens Vazias. Histórico. Disponível em: <http://www.inpev.org.br/institucional/historico/historico.asp. Acesso em: jan. 2006.

26. INPEV - Instituto Nacional de Processamento de Embalagens Vazias. Recolhimento embalagens vazias. Disponível em: <http://www.inpev.org.br/destino_embalagens/estatisticas/br/teEstatistica.asp. Acesso em set. 2005.

27. BRASIL. LEI $n^{\circ} 7802$ de 11 de julho de 1989. Diário Oficial [da] República Federativa do Brasil. Poder Executivo, Brasília, DF, 12 jul. 1989. Seção 1. p. $11459 / 60$.

28. ANDEF - Associação Nacional de Defesa Vegetal. Destinação final de embalagens vazias de agrotóxicos. Disponível em: $<$ http://www.andef.com.br/dest_final/. Acesso em jan. 2005.

29. ABNT - ASSOCIACÃO BRASILEIRA DE NORMAS TÉCNICAS. NBR 13968: Embalagem rígida vazia de agrotóxicos: procedimento de lavagem. Rio de Janeiro, 1997b.

30. DALMEIDA, M. L. O.; VILHEMA, A. Manual de gerenciamento integrado. IPT/CEMPRE. Publicação IPT 2622, São Paulo, 2000. cap. IV, Processamento do lixo: parte 4: reciclagem do plástico. p. 145-155.

31. NOGUEIRA, R. F. P.; GUIMARÃES, J. R. Processos oxidativos avançados: uma alternativa para o tratamento de efluentes. Engenharia Sanitária e Ambiental. 3(3): 97-100, 1998.

32. TABATA, Y.; ITO, Y.; TAGAWA, S. CRC, Handbook of radiation chemistry. Boca Raton, CRC, 1991. cap. IV, Radiation chemistry of aqueous systems. p. 321-382.

33. PIKAEV, A. K.; SHUBIN, V. N. Radiation treatment of liquid wastes. Radiat. Phys. Chem., 24(1): 77-97, 1984.

34. SAKUMOTO, A.; MIYATA, T. Treatment of waste water by a combined technique of radiation and conventional method. Radiat. Phys. Chem., 24(1): 99-115, 1984.

35. MINCHER, B.; LIEKHUS, K.; ARBON, R. E. Pcb radiolysis in isooctane in the presence of ozone. Appl. Radiat. Isot., 47(8): 713-715, 1996.

36. SOLPAN, D.; GUVEN, O. Dechlorination and degradation of some textile dyes by gamma irradiation. Radiat. Phys. Chem., 65(4-5): 549-558, 2002. 
37.TAIXING, W.; CRUZ, V.; MEZYK, S.; COOPER, W. J.; O'SHEA, K. E. Gamma radiolysis of methil t-butil ether: a study of hydroxyl radical mediated reaction pathways. Radiat. Phys. Chem., 65(4-5): 335-341, 2002.

38. DUARTE, C. L.; GERARDO, L. L.; JUNIOR, O. A. P.; BORRELY, S. I.; SATO, I. M.; SAMPA, M. H. O. Treatment of effluentes from petroleum production by electron beam irradiation. Radiat. Phys. Chem., 71(1-2): 445-449, 2004.

39. CHITOSE, N.; UETA, S.; SEINO, S.; YAMAMOTO, T. A. Radiolysis of aqueous phenol solutions with nanoparticles. Phenol degradation and toc removal in uv, $\gamma$-ray and electron beams. Chemosphere. 50(8): 1007-1013, 2003.

40. ZHANG, S. J.; YU, H. Q. Radiation-induced degradation of polyvinil alcohol in aqueous solutions. Water Research. 38(2): 309-316, 2004.

41.POPOV, P.; GETOFF, N. Radiation-induced degradation of aqueous fluoranthene. Radiat. Phys. Chem., 72(1): 19-24, 2005.

42. WASIEWICZ, M.; CHMIELEWSKI, A. G.; GETTOFF, N. Radiation-induced degradation of aqueous 2,3-dihydroxynaphtalene. Radiat. Phys. Chem., 75(2): 201-209, 2006.

43. WINDL, F. M.; SGRILLO, R. B. Degradação do malathion por meio de radiações ionizantes gama do cobalto 60. Ciencia e Cultura. 34(7): 917-921, 1982.

44.JAVARONI, R. C. A.; TALAMONI, J.; LANDGRAF, M. D.; REZENDE, M. O. O. Estudo da degradação de lindano em solução aquosa através de radiação gama. Química Nova. 14(4): 237-239, 1991.

45. YOUNGKE, H.; HONGTAO, C.; XIANGRONG, S.; JILAN, W. Radiationinduced dechlorination of hexachlorobenzene. Radiat. Phys. Chem., 42(4-6): 715-717, 1993.

46. LANDGRAF, M. D.; VIEIRA, E. M.; REZENDE, M. O. O.; LUCHINI, L. C. Estudo da degradação do inseticida parattion através da radiação gama do cobalto 60. Química Nova. 19(4): 353-356, 1996.

47. LUCHINI, L. C.; PERES, T. B.; RESENDE, M. O .O. Degradation of insecticide paration in methanol by gamma-irradiation. Journal of Radioanalytical and Nuclear Chemistry. 241(1): 191-194, 1999.

48. VEL LEITNER, N. K.; BERGER, P.; GEHRINGER, P. Gamma-irradiation for the removal pf atrazine in aqueous solution containing humic substances. Radiat. Phys. Chem., 55(3): 317-322, 1999.

49. ANGELINI, G.; BUCCI, R.; CARNEVALETTI, F.; COLOSIMO, M. Radiolytic decomposition of aqueous atrazine. Radiat. Phys. Chem., 59(3): 303-307, 1998. 
50. ABDEL AAL, S. E.; DESSOUKI, A. M.; SOKKER, H. H. Degradation of some pesticides in aqueous solutions by electron beam and gamma-radiation. Journal of Radioalytical and Nuclear Chemistry. 250(2): 329-334, 2001.

51.ZONA, R.; SOLAR, S.; GEHRINGER, P. Degradation of 2,4dichlorophenoxyacetic acid by ionizing radiation: influence of oxygen concentration. Water Research. 36(5): 1369-1374, 2002.

52.ZONA, R.; SOLAR, S. Oxidation of 2,4-dichlorophenoxyacetic acid by ionizing radiation: degradation, detoxication and mineralization. Radiat. Phys. Chem., 66(2): 137-143, 2003.

53.PANG, G. F.; CHAO, Y. Z.; FAN, C. L.; ZHANG, J. J.; LI, X. M. Modofication of aoac multiresidue method for determination of synthetic pyrethroid residues in fruits, vegetables, and grains. Part I: acetonitrile extraction system and optimization of florisil cleanup and gas chromatography. Journal of AOAC International. 78(6): 1481-1488,

54. FERNANDEZ-ALBA, A. R.; AGUERA, A.; CONTRERAS, M.; PENULA, G.; FERRER, I.; BARCELO, D. Comparison of various samples handling and analytical procedures for the monitoring of pesticides and metabolites in ground waters. Journal of Chromatography A. 823(1-2): 35-47, 1998.

55.STAN, H.; LINKERHAGNER, M. Pesticide residue analysis in foodstuffs applying capillary gas chromatography with atomic emission detector state-ofthe-art use modified multimethod s19 of the deutsche forschungsgemeinschaft and automated large-volume injection with programmed-temperature vaporization and solvent venting. Journal of Chromatography A. 750(1-2 ): 369-390, 1996.

56. BERNAL, J. L.; DEL NOZAL, M. J.; MARTIN, M. T. Possibilities of gas chromatography-atomic emission detection in pesticide multiresidue analysis application to herbicide analysis in soils. Journal of Chromatography A. 754(1-2 ): 245-256, 1996.

57. MIYAHARA, M.; OKADA, Y.; TAKEDA, H.; AOKI, G.; KOBAYASHI, A.; SAITO, $Y$. Multiresidue procedures for the determination of pesticides in food using capilary gas chromatographic, flame photometric, and mass spectrometric techniques. J. Agr. Food Chem., 42(12): 2795-2802, 1994.

58. HATRIK, S.; TEKEL, J. Extraction methodology and chromatography for the determination of residual pesticides in water. Journal of Chromatography A. 733(1-2): 217-233, 1996.

59. LEE, S. M.; WYLIE, P. L. Comparision of the atomic emission detector to other element-selective detectors for the gas chromatographic analysis of pesticide residues. J. Agr. Food Chem., 39(12): 2192-2199, 1991. 
60.BAVCON, M.; TREBSE, P.; ZUPANCIC-KRALJ, L. Investigations of the determination and transformations of diazinon and malathion under environmental conditions using gas chromatography coupled with a flame ionization detector. Chemosphere. 50(5): 595-601, 2003.

61. JIN, H.; WEBSTER, G. R. B. Determination of chlorpyrifos, its oxon, and 3,5,6thrichloro-2-pyridinol in soil, elm bark, and litter following applications for control of the elm bark beetle. Intern. J. Environ. Anal. Chem., 69(4): 307316, 1998.

62. CHUANG, J. C.; VAN EMON, J. M.; REED, A. W.; JUNOD, N. Comparison of immunoassay and gas chromatograph/mass spectrometry methods for measuring 3,5,6-thricloro-2-pyridinol in multiple sample media. Analytica Chimica Acta. 517(1-2): 177-185, 2004.

63. VIDAL, J. L. M.; ESPADA, M. C. P.; FRENICH, A. G.; ARREBOLA, F. J. Pesticide trace analysis using solid-phase extraction and gas chromatograph with electron capture and tandem mass spectrometric detection in water samples. Journal of Chromatography A. 867(1-2):235-245, 2000.

64. AGUILAR, C.; PEÑALVER, S.; POCURULL, E.; BORULL, F.; MARCÉ, R. M. Solid-phase microextraction and gas chromatography with mass spectrometric detection for the determination of pesticides in aqueous samples. Journal of Chromatography A. 795(1): 105-115, 1998.

65. DOW AGROSCIENCE. Ficha de informação de segurança de produtos químicos - $\quad$ fispq. $\quad$ Disponível em: <http://www.dowagro.com/webapps/lit/litorder.asp?filepath=br/pdfs/noreg/013.0 1004.pdf\&pdf=true. Acesso em fev 2005.

66. KULKARNI, A. R.; SOPPIMATH, K. S.; DAVE, A. M.; MEHTA, M. H.; AMINABHAVI, T. M. Solubility study of harzardous pesticide (chlorpyrifos) by gas chromatography. Journal of harzardous materials. A80: 9-13, 2000.

67. DUARTE, C. L.; SAMPA, M. H. O.; RELA, P. R.; OIKAWA, H.; SILVEIRA, C. G. Advanced oxidation process by electron-beam-irradiation induced decomposition of pollutants in industrial effluents. Radiat. Phys. Chem., 63 (36): 647-651, 2002.

68. SMITH, G. N.; WATSON, B. S.; FISHER, F. S. Investigation on dursban insecticide. Metabolism of $\left[{ }^{36} \mathrm{Cl}\right]$ O,O-dyethil O-(3,5,6-trichloro-2-pyridil) phosphorothioate in rats. J. Agr. Food Chem., 1(1):132-138, 1967.

69. SMITH, G. N.; WATSON, B. S.; FISHER, F. S. Investigation on dursban insecticide. Uptake and translocation of $\left[{ }^{14} \mathrm{C}\right]$ O,O-dyethil O-(3,5,6-trichloro-2pyridil) phosphorothioate by beans and corn. J. Agr. Food Chem., 1(1):127131, 1967. 
70. LIU, B.; McCONNEL, L. L.; TORRENTS, A. Hydrolysis of chlorpyrifos in natural waters of the cheseapeake bay. Chemosphere. 44(6): 1315-1323, 2001.

71. DUARTE, C. L. Aplicação do processo avançado de oxidação por feixe de elétrons na degradação de compostos orgânicos presentes em efluentes industriais. Tese apresentada no Instituto de Pesquisas Energéticas e Nucleares, Ipen, para a obtenção do grau de Doutor em Ciências, Área de Concentração: Tecnologia Nuclear: Aplicações. São Paulo - SP - Br. Dez de 1999.

72. DEMATTEO, M. P.; POOLE, J. S.; SHI, X.; SACHDEVA, R.; HATCHER, P. G.; HADAD, C. M.; PLATZ, M. S. On the electrophilicity of hydroxil radical: a laser flash photolysis and computacional study. J. Am. Chem. Soc., 127(19): 70947109, 2005.

73. GARRET, B. C.; DIXON, D. A.; CAMAIONI, D. M.; CHIPMAN, D. M.; JOHNSON, M. A.; ZWEIR, T. S. Role of water in electron-initiates process and radical chemistry: issues and scientific advances. Chem. Rev., 105(1): 355389, 2005. 